\title{
7. DEFORMATION OF Fe-Ti OXIDES IN GABBROIC SHEAR ZONES FROM THE MARK AREA ${ }^{1}$
}

\author{
Susan M. Agar² and Geoffrey E. Lloyd ${ }^{3}$
}

\begin{abstract}
The migration of late-stage magmatic fractions along shear zones at seafloor spreading centers will modify bulk composition, temperature, and fluid chemistry, as well as pressure during deformation. These changes will influence the rheological evolution of oceanic shear zones and the time-dependent strength of the ocean crust. Fe-Ti oxides, representing late-stage magmatic fractionates, are volumetrically abundant ( $>50 \%$ in some instances) in many of the core-scale shear zones recovered from Ocean Drilling Program Sites 921, 922, and 923. Yet, little is known about the role of these phases during shear-zone deformation, the mechanisms by which they deform, and the timing of melt migration relative to deformation. Using orientation contrast imaging and selected area diffraction (electron channeling), the petrofabrics and microstructures of $\mathrm{Fe}$-Ti oxides in three texturally contrasting shear zones were determined. Magnetite preserves no strong crystallographic preferred orientation in any of the samples. Ilmenite exhibits a strong preferred orientation in one sample where the [0001] direction is oriented at a high angle to the shear plane. Deformation mechanism maps, grain-size variations, and paleotemperature estimates of $550^{\circ}-650^{\circ} \mathrm{C}$, indicate that the magnetite in two of the samples deformed predominantly by diffusion creep. Ilmenite deformed by dislocation creep in one sample and probably by diffusion creep in a second sample. Melt-assisted grain boundary sliding with post-kinematic grain growth could also account for the lack of crystallographic preferred orientation of recrystallized oxides. In a third sample, primary textures may persist in both magnetite and ilmenite. Through the interaction of magmatic fractionation and deformation, relatively weak phases were concentrated in shear zones during an overall down-temperature deformation path $\left(>900^{\circ}-550^{\circ} \mathrm{C}\right)$. Our results and other investigations of metamorphic ores suggest that $\mathrm{Fe}-\mathrm{Ti}$ oxides behave as highly ductile phases even at low temperatures $\left(200^{\circ}-400^{\circ} \mathrm{C}\right)$. This property, combined with an ore-concentrating mechanism in shear zones, will promote aseismic creep at relatively shallow levels in the ocean crust $(<2 \mathrm{~km})$ and may partly account for the low levels of seismicity along spreading-segment faults.
\end{abstract}

\section{INTRODUCTION}

Rheological modeling of the lower oceanic crust has commonly employed flow laws derived from experimental data on monomineralic lithologies, usually olivine or serpentine. A diverse suite of gabbros recovered during Ocean Drilling Program (ODP) Leg 153 (Sites 921-924), interpreted to have formed at mid-lower crustal depths (Cannat, Karson, Miller, et al., 1995), reveals that neither of these phases is present in volumetrically high proportions within numerous shear zones that accommodated crustal deformation. The matrix of porphyroclastic and mylonitic shear zones is generally dominated either by plagioclase or $\mathrm{Fe}$ - $\mathrm{Ti}$ oxides. An $\mathrm{Fe}$-Ti-oxide enrichment was also noted in gabbroic shear zones recovered during ODP Leg 118 (Southwest Indian Ridge). These observations were used to construct a preliminary model in which a deformation-enhanced permeability in high-temperature shear zones provided migration paths for latestage magmatic fractionates (e.g., Bloomer et al., 1991).

An important consequence of the association between magmatism and shear zones is that the composition and physical properties (and therefore rheology) of the shear zones can differ significantly from the bulk crustal composition. A rheological contrast between the bulk protolith and the shear zone is promoted further by the changes in the thermal, chemical, and fluid-pressure environments induced by melt migration. With the recent ODP core recovery of young plutonic sections at mid-ocean ridges, it is now possible to establish representative mineralogies of oceanic shear zones and compare their rheological behavior with that predicted by established flow laws for olivine or serpentine. Furthermore, it is important to investigate the roles of

'Karson, J.A., Cannat, M., Miller, D.J., and Elthon, D. (Eds.), 1997. Proc. ODP, Sci. Results, 153: College Station, TX (Ocean Drilling Program).

${ }^{2}$ Geological Sciences Department., Northwestern University, Evanston, IL 60208 . U.S.A. agar@earth.nwu.edu

${ }^{3}$ Earth Sciences Department, University of Leeds, Leeds, LS2 9JT, United Kingdom. varying proportions of different phases in polyphase shear-zone assemblages.

This paper presents the results of a pilot study on three texturally contrasting gabbroic shear zones from Holes $921 \mathrm{E}$ and $922 \mathrm{~A}$, drilled during Leg 153, to determine the deformation mechanisms and the conditions of deformation in Fe-Ti-oxide-dominated mineralogies. Although the ODP drilling at the Mid-Atlantic Ridge Kane Fracture Zone (MARK) area and the Southwest Indian Ridge has focused attention on the linked mechanisms of lower crustal shearing and melt migration, the significance of these findings is not limited to oceanic settings. Recent studies (e.g., White and Gibbons, 1994; Housen et al., 1995) have also recognized the volumetrically significant presence of oxide phases in shear-zone deformation in amphibolite-togranulite facies terrains in lower continental crustal sections. The results of this study and on-going research may therefore have more wide-ranging applications to lithospheric rheology in general.

\section{TECTONIC SETTING OF SITES 921 AND 922}

Sites 921 and 922 are located $10 \mathrm{~km}$ south of the Kane Transform on the western wall that forms the edge of the inner corner high of the Mid-Atlantic Ridge (Fig. 1). These sites penetrated the seafloor at depths ranging from 2500 to 2650 meters below seafloor (mbsf), 500-600 m below the peak of the inner corner high, close to the location of previous ODP drilling at Site 669 (Detrick, Honnorez, Bryan, Juteau, et al., 1988), which penetrated a basaltic carapace at $1980 \mathrm{~m}$ water depth (Fig. 1). Magnetic anomalies indicate asymmetric crustal spreading over the last 2 million yr with spreading rates of $14.1 \mathrm{~mm} / \mathrm{yr}$ to the west and $11.3 \mathrm{~mm} / \mathrm{yr}$ to the east (Schulz et al., 1988). Both sites are located in approximately 1-m.y.-old crust. The exposure of gabbroic and ultramafic lithologies in this region (e.g., Karson and Dick, 1983; Mével et al., 1991) has been attributed to exhumation by a major low-angle normal detachment fault (Dick et al., 


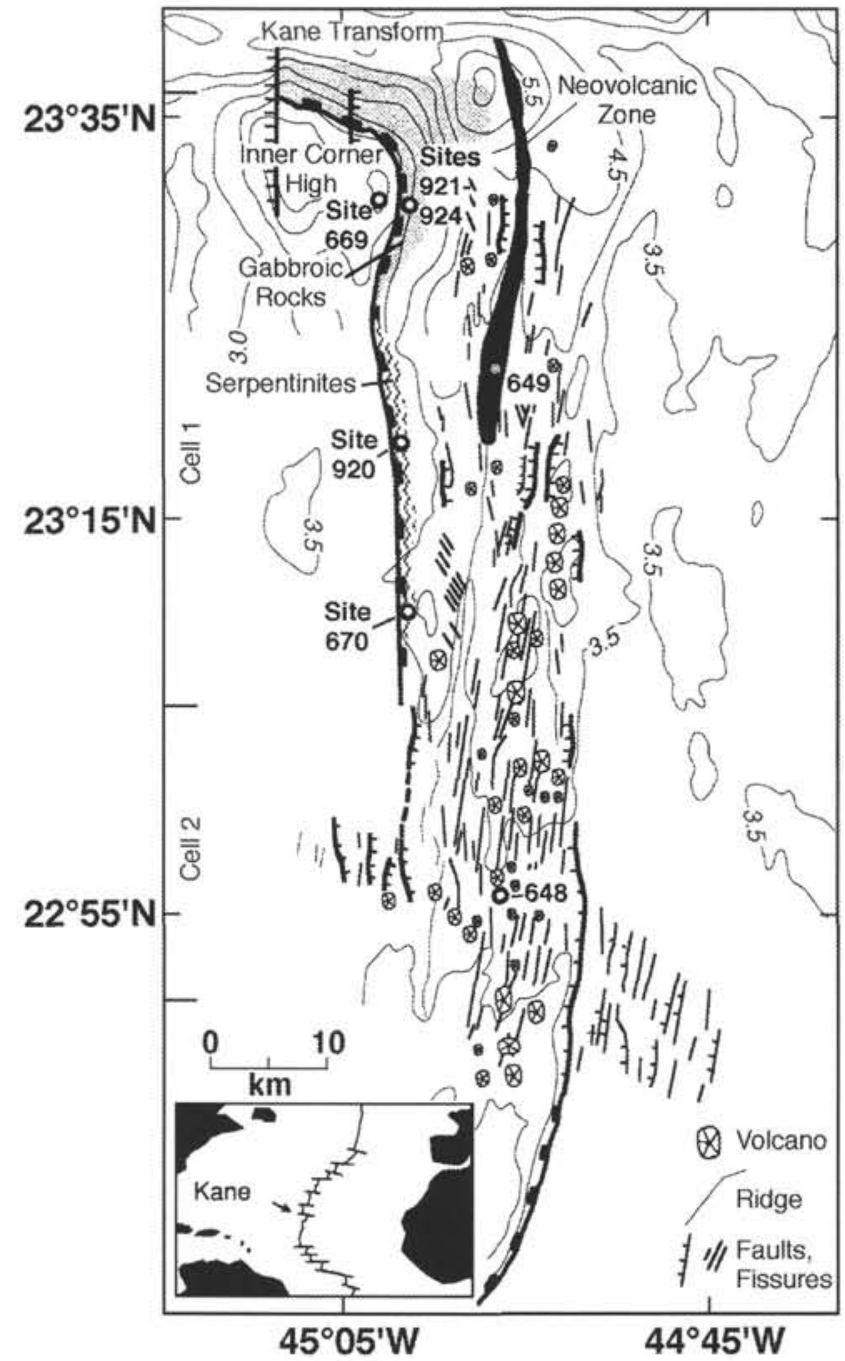

Figure 1. Location of Sites 921 and 922 on the edge of the inner-corner high of the Mid-Atlantic Ridge, Kane Transform (MARK) area. Modified from Cannat, Karson, Miller, et al. (1995). Other Leg 153 drill sites and previous ODP/Deep Sea Drilling Project sites are also indicated. Zones of gabbroic rock (stipple) and serpentinite exposures (squiggles) and the neovolcanic zone (black) are shown. Bathymetric depth contours are in kilometers.

1981; Karson and Dick, 1983; Karson et al., 1987) generated during a period of reduced magma supply. In this model, Sites 921 and 922 would be located in the footwall of the detachment fault, and gabbroic rocks would represent middle-to-lower crustal lithologies. Core samples comprise gabbro and olivine gabbro, with smaller proportions of troctolite and $\mathrm{Fe}-\mathrm{Ti}$ - oxide gabbros. These lithologies are cut by veins of leucogabbro, quartz diorite, and trondhjemite, generally thought to represent products of more extensive melt fractionation (Cannat, Karson, Miller, et al., 1995). Overall, there is only limited alteration (represented by amphibolite, greenschist, and sparse zeolite mineral assemblages), but on $\mathrm{mm}$ to $\mathrm{cm}$ scales, the extent of alteration is highly variable.

Samples used in this study were selected from Holes $921 \mathrm{E}$ and 922A (Figs. 1, 2). Cumulative core recovery for Hole 921E was between $11.4 \%$ and $29 \%$, whereas Hole $922 \mathrm{~A}$ had a cumulative recovery of $63.2 \%$. Although Holes $921 \mathrm{E}$ and $922 \mathrm{~A}$ penetrated relatively short sections ( $82.6 \mathrm{~m}$ and $14.6 \mathrm{~m}$, respectively), the core samples exhibit a remarkable diversity in igneous lithologies, degree of alteration, and deformation fabrics. The principal lithologies at Site 921 are variably deformed poikilitic olivine gabbros, gabbro norites, ox-

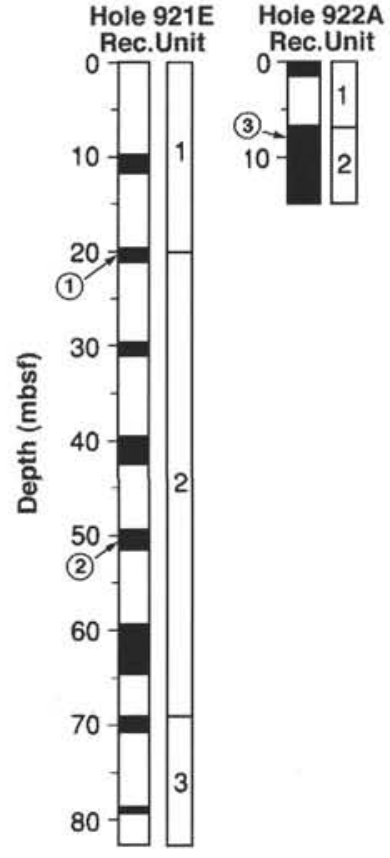

Figure 2. Approximate depth locations of samples used in this study from Holes 921E and 922A. (1) Sample 153-921E-2R-2, 58-60 cm, (2) Sample 153-921E-5R-1, 0-6 cm, (3) Sample 153-922A-2R-5, 83-87 cm. Lithologic units are numbered in the right-hand column. In Hole 922A: $1=$ metatroctolite, 2 = troctolite and olivine gabbro. In Hole 921E: 1 = very coarse-grained to pegmatitic gabbro, 2 = heterogeneous poikilitic olivine gabbro, 3 = varitextured gabbro and olivine gabbro.

ide gabbros, gabbros, and pegmatitic gabbros with cumulus textures. The average alteration intensity ranges from about $9 \%$ to $15 \%$, but is heterogeneous and locally ( $\mathrm{mm}$ to $\mathrm{cm}$ scale) attains values of $80 \%-$ $90 \%$. The oxide gabbro and oxide gabbronorite are thought to have crystallized from melts with relatively evolved compositions (Cannat, Karson, Miller, et al., 1995). During shipboard descriptions, it was noted that oxide-mineral-rich veins are most abundant in the pegmatitic and lineated gabbroic rocks and occur only rarely in the more primitive poikilitic olivine gabbro. Felsic veins cut the gabbros, but the trondhjemitic veins are most abundant in the poikilitic olivine gabbro. The deformation in holes at Sites 921, 922, and 923 is characterized by $\mathrm{m}$ - and $\mathrm{cm}$-scale variations in intensity, ranging from undeformed to pervasively foliated and lineated regions, to localized mylonitic and cataclastic shear zones.

Troctolite and meta-troctolite, olivine gabbro and poikilitic olivine gabbro were recovered with minor oxide gabbro, gabbronorite, and crosscutting gabbroic and felsic magmatic veins at Site 922. Modal layering and magmatic foliations are present, as are harrisitic textures, indicative of cumulus origin, in the troctolite and olivine gabbros. Alteration intensities are generally higher than those of Site 921 , ranging from $20 \%$ to $50 \%$ with local increases to $80 \%-100 \%$. The structures in the Site 922 holes display a similar diversity to those of the Site 921 holes.

\section{SAMPLE SELECTION}

Samples for this study (Pls. 1-4) were chosen during shipboard description from (1) oxide-gabbro intervals where Fe-Ti oxide phases $(<10 \%)$ were relatively evenly distributed through the rock, (2) from planar and curviplanar crystal-plastic shear zones where oxide minerals were concentrated in bands or segregations (30\%-50\%) (PI. 1, Fig. 4; Fig. 3B) or elongate Fe-Ti-oxide-minerals form "stringers" 


\section{$1 \mathrm{~mm}$}

A

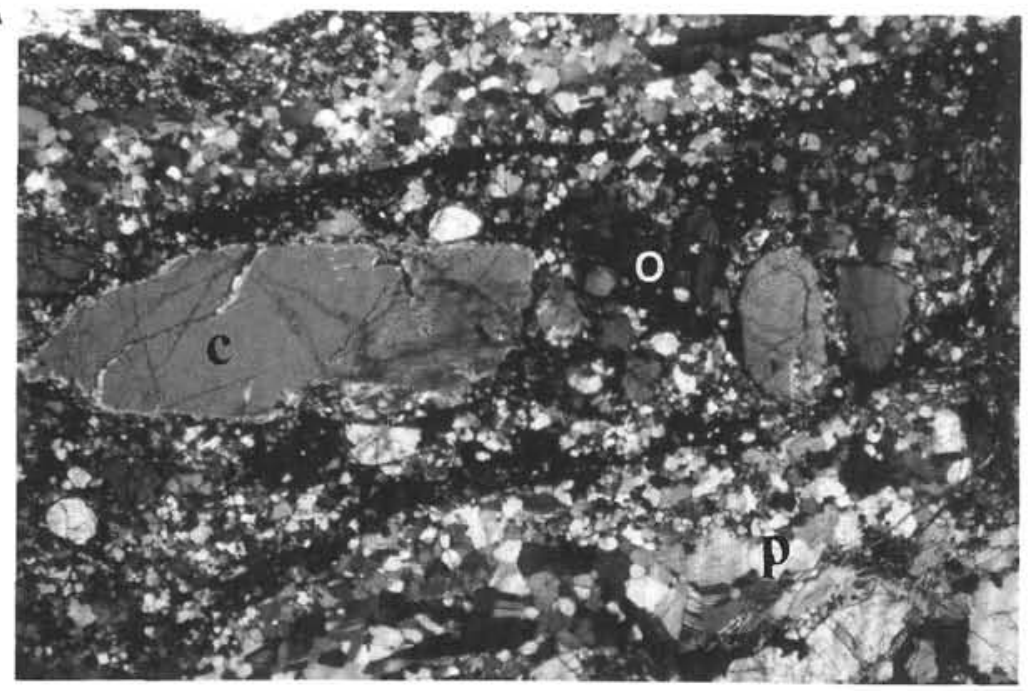

B

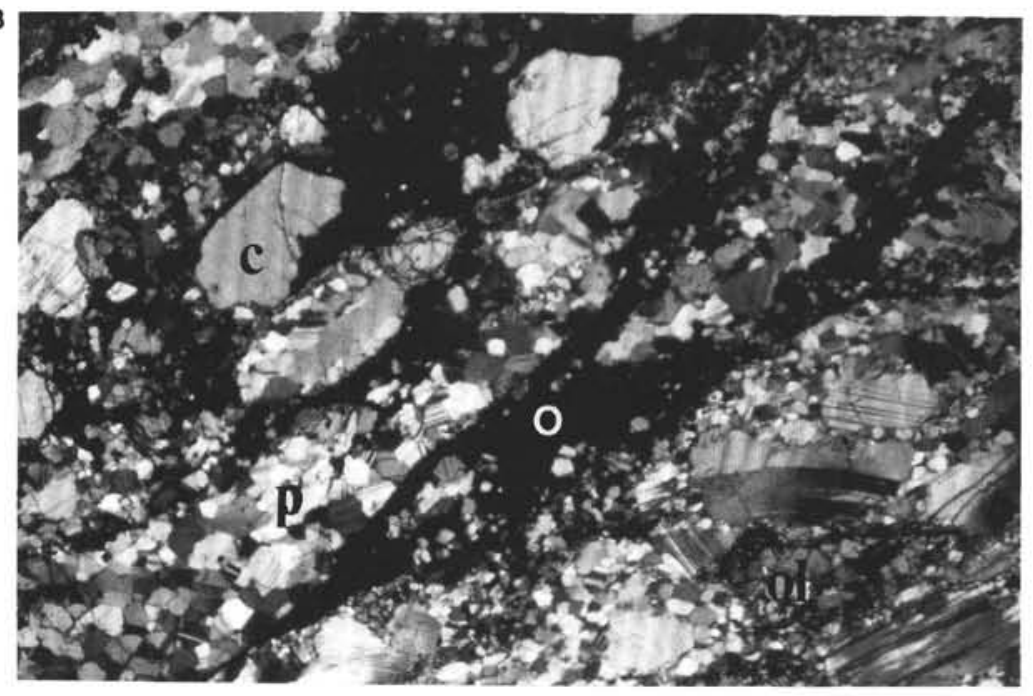

c

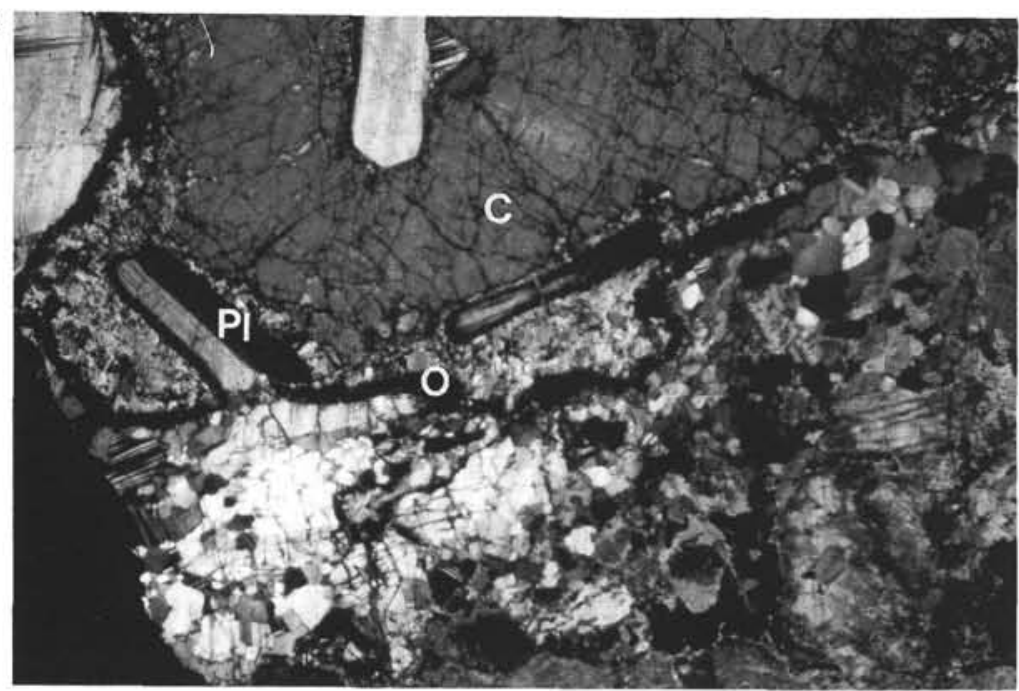

Figure 3. Optical photomicrographs showing the different characteristics of Fe-Ti oxides in samples from Leg 153 (crossed nicols). A. Mylonitic shear zone containing an oxide-rich band ( $o$; black phases). Clinopyroxene is also concentrated in the same band. The large grain (c) is a clinopyroxene porphyroclast with brown amphibole alteration around its margins. Sample 153-922A-2R-2, $0-6 \mathrm{~cm}$. B. Discrete veins of Fe-Ti oxides that cut the dynamically recrystallized plagioclase (p), clinopyroxene, and olivine. Sample 153-921E-3R-1, 37-47 cm. C. Alteration around the rims of clinopyroxene porphyroclasts contain $\mathrm{Fe}$-Ti oxides and brown amphibole. plagioclase $(\mathrm{Pl})$ inclusions, once enveloped by the clinopyroxene grain are now suspended in the altered rim. Dynamically recrystallized plagioclase surrounds the porphyroclast. Sample 153-921E-8R-1, 91-95 cm. 
(Pl. 1, Fig. 3), and (3) from fine-grained $(<50 \mu \mathrm{m})$, mylonitic shear zones where oxides dominate the mineralogy $(\sim 50 \%)$ (Pl. 1, Figs. 1, 2; Fig. 3A). Where possible, the up direction of samples was recorded, but none of the cores was fully oriented.

For this pilot study we concentrated on three texturally contrasting oxide-bearing shear zones:

1. Sample $153-922 \mathrm{~A}-2 \mathrm{R}-5,83-87 \mathrm{~cm}$, is located in Unit 2 of Hole $922 \mathrm{~A}$, consisting of primarily olivine gabbro, but also including troctolite, metatroctolite, oxide gabbro, and oxide gabbronorite, as well as felsic veins, some of which are oxidemineral rich. The mineralogy of this shear zone and other oxide-rich zones commonly encountered in both Holes 922A and 922B typically includes plagioclase-clinopyroxene-orthopyroxene \pm titanomagnetite \pm ilmenite \pm apatite \pm zircon. This sample comes from a curviplanar shear zone (about $3 \mathrm{~cm}$ wide) between 80 and $110 \mathrm{~cm}$, which links on the right side of the archive core to another, similar but mirror-image, structure below it (Pl. 1, Fig. 4; PI. 2). The shear zone is characterized by a shape-preferred orientation of pyroxene in a dynamically recrystallized matrix of plagioclase, together with segregations of Fe-Ti oxides, oriented subparallel to the foliation defined by the pyroxene and plagioclase porphyroclast orientations (Pl. 2). The shear-zone dips range from subhorizontal to greater than $70^{\circ}$ across the core face. It was not possible to ascertain whether this geometry was a result of folding or possibly the intersection of two anastomosing shear zones. Actinolite and chlorite veins cut across the shear zone. Background alteration varies between $40 \%$ and $60 \%$, but is very heterogeneous.

2. Sample 153-921E-5R-1, 0-6 cm, is located within an olivine gabbro unit (Unit 2 of Hole 921E; Pl. 1, Fig. 2; Pl. 3). Igneous textures from Hole $921 \mathrm{E}$ are dominantly cumulate, ranging from equigranular to highly inequigranular. This shear-zone sample was taken from an oxide gabbro containing up to $10 \%$ oxide minerals that occur both interstitially and in thin layers up to $20 \mathrm{~mm}$ long within a 15 -mm-wide shear zone. Elongate plagioclase and oxide minerals surround altered pyroxene porphyroclasts. The bulk mineralogy outside the shear zone is oxide minerals $10 \%$, plagioclase $60 \%-65 \%$, clinopyroxene $27 \%-38 \%$, and $2 \%-4 \%$ olivine. Within the shear zone, the percentage of Fe-Ti oxides increases locally to more than $80 \%$. The shear zone is approximately planar, but the piece is unoriented so the dip is unknown.

3. Sample $153-921 \mathrm{E}-2 \mathrm{R}-2,58-60 \mathrm{~cm}$, is located above the contact between a pegmatitic gabbro and a pegmatitic olivine gabbro in Hole 921E (Pl. 1, Fig. 1; Pl. 4). Modal variations occur over short lengths (cm scale) throughout this core section, and clinopyroxene varies between $40 \%$ and $80 \%$, olivine between $0 \%$ and $10 \%$, plagioclase between $14 \%$ and $48 \%$, and oxide minerals between $1 \%$ and $2 \%$. The foliation intensity diminishes away from the shear zone over a $20-\mathrm{cm}$ interval. The shear zone comprises a 2-cm-thick, subhorizontal mylonite containing plagioclase, clinopyroxene, $\mathrm{Fe}-\mathrm{Ti}$ oxides $(30 \%-$ $50 \%$ ), apatites, and zircons. Millimeter-scale segregations are evident. Pyroxene tends to be concentrated with Fe-Ti oxides, whereas plagioclase tends to form separate bands (PI. 4).

\section{METHODS}

\section{Optical Microscopy, Backscattered Electron Imaging, and Electron Microprobe Analysis}

Specimens were examined optically in thin section $(30 \mu \mathrm{m})$ and by backscattered electron imaging (BSE) using polished resin blocks. Resin blocks were prepared according to the procedures outlined in
Fynn and Powell (1979). This technique uses a combination of mechanical and chemical polishing of samples to remove the surface damage from mechanical grinding. Images were acquired using a CAMSCAN Series 4 scanning electron microscope (SEM), which incorporates a dynamic selected area diffraction (SAD) attachment and a KEE electronics, 4-quadrant, solid-state, BSE detector. Modal estimates were made from point counts of thin sections and from photomosaics compiled from BSE images.

Electron microprobe analyses for ilmenite and magnetite were acquired using wavelength dispersive analysis on a JEOL 733 Superprobe. The analyses were compared with those obtained using a CAMECA electron microprobe and different mineral standards. Raw data were reduced using the Bence-Albee routine.

\section{Crystallographic Fabrics Determined by Electron Channeling}

Because of the opaque nature of the Fe-Ti-oxide phases, neither a full crystallographic orientation nor the internal microstructures can be easily identified by optical methods. Although neutron diffraction or texture goniometry can be used to derive the bulk fabric for a massive ore, the electron channeling technique provides a means to examine the orientation of distinct phases on a grain-to-grain basis (Lloyd et al., 1981; Lloyd, 1985, 1987). Produced by the diffraction of electrons as they pass through the crystal lattice, electron channeling patterns can be readily acquired in conjunction with high-resolution backscatter imaging. This approach provides the necessary resolution to understand the detailed relationships between the grains of different phases, their chemical variations, and microstructures.

Electron channeling patterns (ECPs) were acquired for ilmenite and magnetite. In Sample 153-922A-2R-1, 83-87 cm, three different regions were investigated (fine-grained, coarse-grained, and pressure shadow; Pl. 2). The ECPs contain a unique arrangement of bands of different intensities and widths that can be used to determine the crystallographic orientation. The program CHANNEL (Schmidt and Olesen, 1989) was used to compare the ECP for each grain (or subgrain) with a computer-generated map of the crystal lattice for either magnetite or ilmenite. This map was generated by entering the Laue group together with the atomic species and their lattice locations for each phase. Once a visual match between the computer-generated map and ECP was established, the orientations of key crystallographic directions were plotted in lower hemisphere projections (Figs. 4 7).

\section{Grain-Size Measurements}

\section{Identification of Grain Boundaries}

The overall fine grain size of the shear zones means that the highresolution orientation contrast images resolve more of the grain-size spectrum than would be resolvable by optical methods. A further source of error in optical imaging is the difficulty in identifying and assigning grain boundaries. Orientation contrast imaging provides a valuable aid for grain boundary determination, but it can also give rise to ambiguous interpretations. Grain boundaries were defined by junctions with different phases and/or a break in the polished surface of the grain, evident either as a continuous "joint" or a series of linked joints along the grain boundary. Grain boundaries between magnetite grains were commonly identifiable by traces of small cavities along the grain boundary where material may have been dissolved. Open cracks with grain-boundary morphologies that formed after shearing either during exhumation of the gabbros or during sample preparation may have induced some errors. The cracks are often transgranular, but not always. Subgrain boundaries were defined where a change in the backscatter intensity occurred, but there was no break in the polished surface of a single grain. 

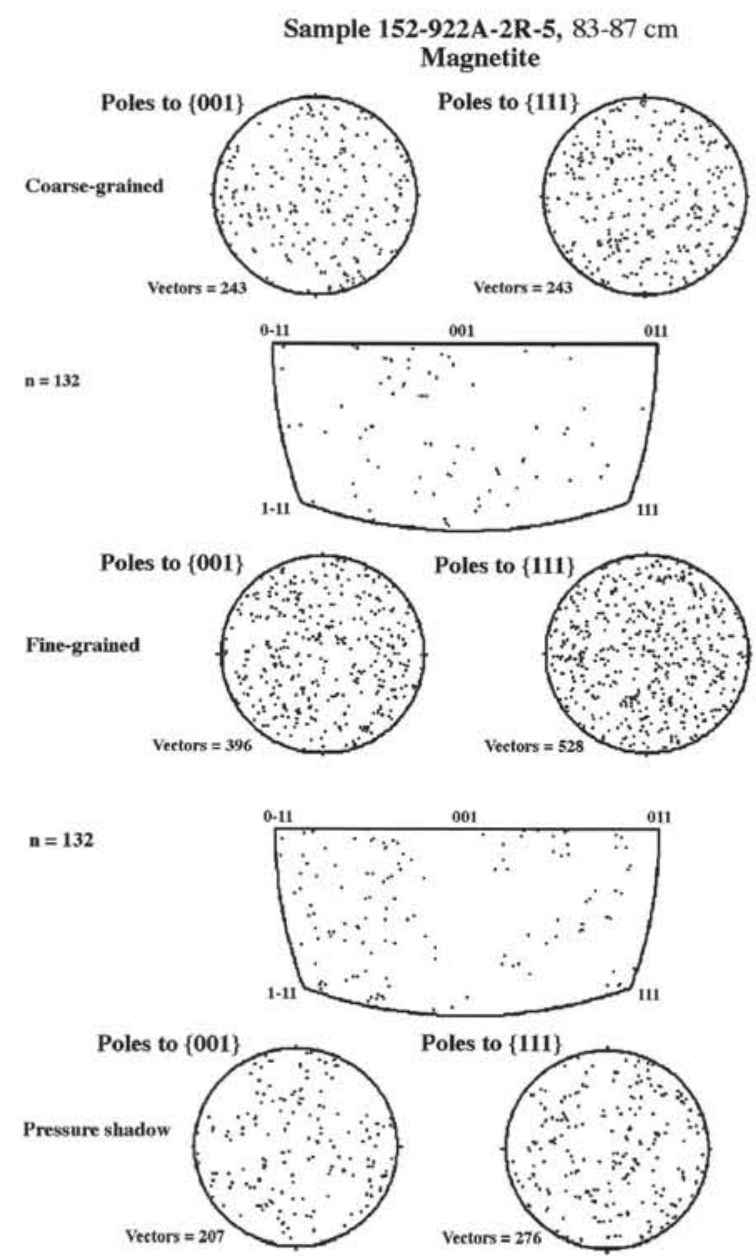

$n=69$

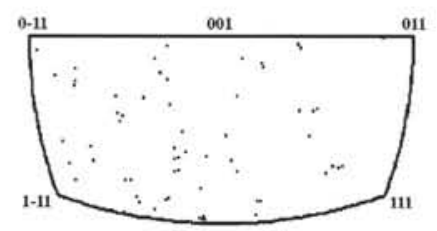

Figure 4. Magnetite fabrics in Sample 153-922A-2R-5, 83-87 cm. Stereographic projections show the $\{001\}$ and $\{111\}$ directions for coarse-grained (CG), fine-grained (FG), and pressure shadow (PS) regions. Crystallographic pole figures are plotted from electron channeling patterns. Stereographic plots are equal-area, lower hemisphere projections. Inverse pole figures are shown beneath each set of stereoplots. All stereoplots are in the same reference frame with the margin of the shear zone oriented vertically in an eastwest direction. The number of grains (n) measured for each sample is indicated. The crystal symmetries of magnetite and ilmenite mean that larger numbers of points can be plotted for some crystal directions (multiples of the numbers of grains depending on the symmetry).

\section{Measurement Procedures}

Chord lengths (the distance between two boundaries on either side of a single phase) were measured along two orthogonal arrays of transects, parallel and perpendicular to the shear-zone margins, spaced at $1 \mathrm{~cm}$ on each photomontage. Chord lengths for each phase and the length of each transect were recorded. Chord-length distributions were normalized for transect lengths and spherical geometries following the technique of Spektor (1950) to obtain the volume percent distribution for each grain-size subdivision, ranging from 5 to 20

\section{Sample 153-921E-5R-1, 0-6 cm Magnetite}
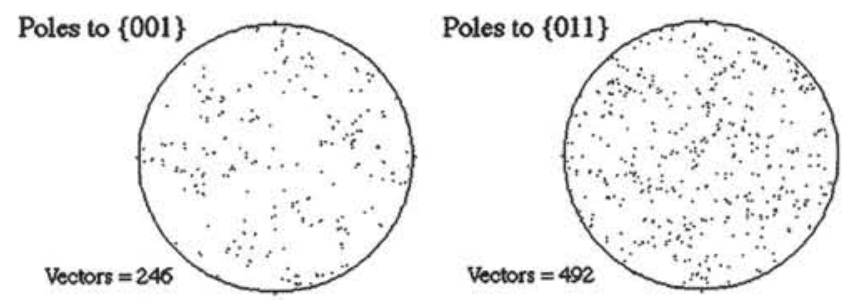

Poles to $\{111\}$

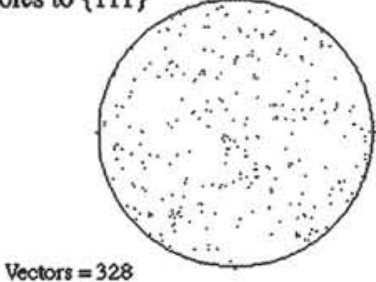

Poles to $\{112\}$
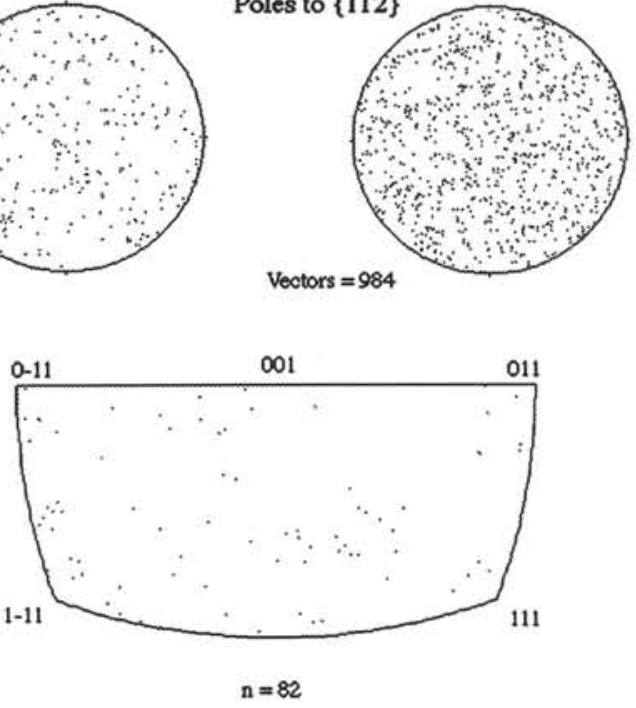

Figure 5. Magnetite fabrics in Sample 153-921E-5R-1, 0-6 cm. Stereographic projections show the $\{001\},\{011\},\{111\}$, and $\{112\}$ directions for the whole sample. Crystallographic pole figures are plotted from electron channeling patterns. Stereographic plots are equal-area, lower hemisphere projections. Inverse pole figures are shown beneath each set of stereoplots. All stereoplots are in the same reference frame with the margin of the shear zone oriented vertically in an east-west direction. The number of grains (n) measured for each sample is indicated. The crystal symmetries of magnetite and ilmenite mean that larger numbers of points can be plotted for some crystal directions (multiples of the numbers of grains depending on the symmetry).

$\mu \mathrm{m}$. The number of particles of mean diameter $\left(N_{\mathrm{v}}\right) \mathrm{j}_{\Delta}$ per unit volume in the interval $\mathrm{j} \Delta \pm \Delta / 2$ is given by

$$
\left(N_{\mathrm{v}}\right) \mathrm{j}=4 / \pi \Delta^{2}[([n L] j /(2 \mathrm{j}-1))-((n L) j+1 /(2 j+1))]
$$

where $(n L) j$ and $(n L) j+1$ are the number of chord lengths in the adjacent size intervals $j$ and $j+1$, and $\Delta$ is the range of each interval (bin size). This method corrects for the range of chord lengths that will result from measurements on a single sphere, ranging from infinitely small to the maximum diameter, with the maximum frequency obtained for the maximum chord length, (i.e., the true diameter of the sphere; Lord and Willis, 1951).

\section{Stereology}

The data were then stereologically corrected assuming an approximately spherical grain shape. The lack of preferred dimensional ori- 
Sample 153-921E-5R-1, 0-6 cm IImenite
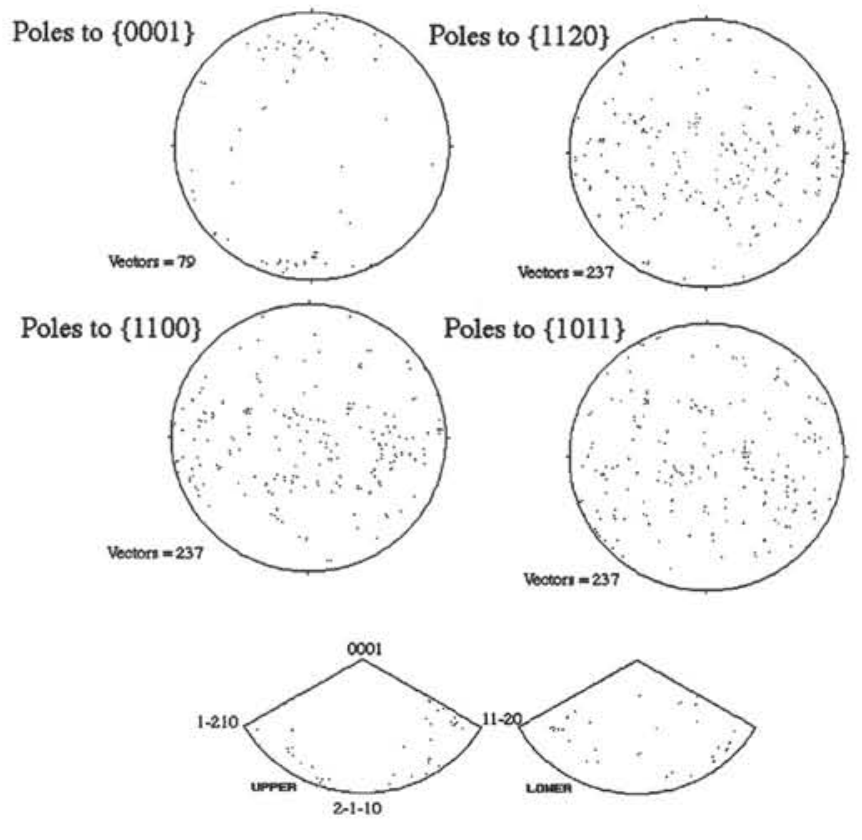

$\mathrm{n}=79$

Figure 6. Ilmenite fabrics in Sample 153-921E-5R-1, 0-6 cm. Stereographic projections show the $\{0001\},\{11-20\},\{1-100\}$, and $\{10-11\}$ directions. Crystallographic pole figures are plotted from electron channeling patterns. Stereographic plots are equal-area, lower hemisphere projections. Inverse pole figures are shown beneath each set of stereoplots. All stereoplots are in the same reference frame with the margin of the shear zone oriented vertically in an east-west direction. The number of grains (n) measured for each sample is indicated. The crystal symmetries of magnetite and ilmenite mean that larger numbers of points can be plotted for some crystal directions (multiples of the numbers of grains depending on the symmetry).

entation of grains of either phase makes this approximation reasonably valid. It can also be shown that other, inequant grain shapes will not increase the grain-size distribution values (mean tangent diameter) by more than a factor of about 1.2 for a sphere of equal volume (Russ, 1986). Measurements from a two-dimensional section will tend to underrepresent small grains. This error is probably compensated by the measuring technique that tends to overrepresent small grain sizes, as apophyses from larger grains will be measured as separate grains.

\section{MICROSTRUCTURES}

\section{Sample 153-922A-2R-5, 83-87 cm}

The shear zone in this sample is defined by a concentration of magnetite and ilmenite within a zone $10-15 \mathrm{~mm}$ wide. The bulk mineralogy of the entire shear zone comprises approximately $5 \%$ ilmenite, $10 \%-15 \%$ magnetite, $25 \%-35 \%$ pyroxene (primarily clinopyroxene), and up to $50 \%$ plagioclase. Within the shear zone, however, there are distinct oxide-mineral-rich bands that separate domains of dynamically recrystallized plagioclase, clinopyroxene, and orthopyroxene. Fe-Ti oxides comprise more than $50 \%$ of the mineralogy, with a 2:1 ratio between magnetite and ilmenite. These Fe-Ti-oxide-rich bands trend subparallel to and oblique $\left(30^{\circ}-40^{\circ}\right)$ to the margins of the shear zone. In some places, the oxide-rich zone envelopes single or polycrystalline domains of pyroxene and plagioclase. A single clinopyroxene crystal shown in Plate 2 is "suspended"
Sample 153-922A-2R-2, 0-6 cm

Magnetite
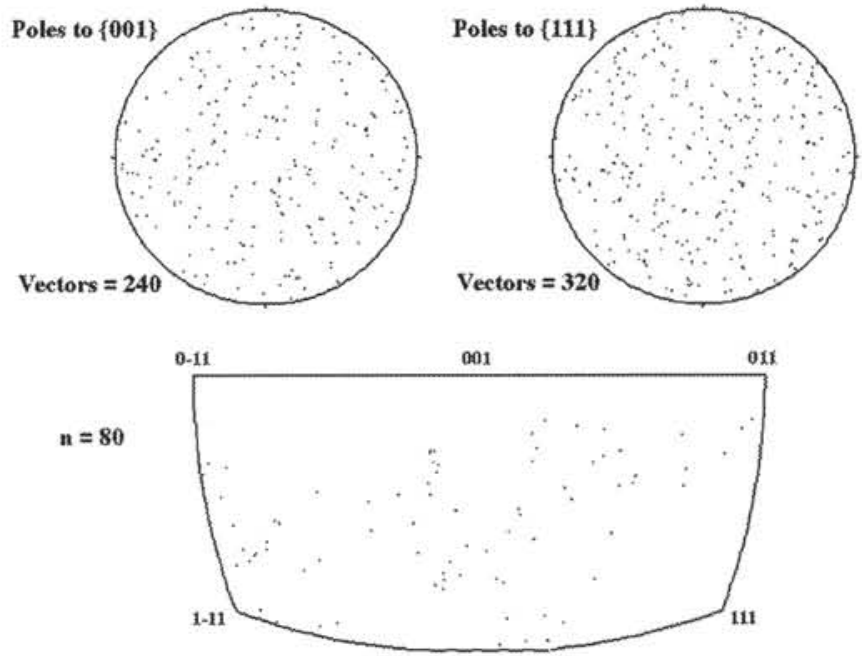

Figure 7. Magnetite fabrics in Sample 153-921E-2R-2, 58-60 cm. Stereographic projections show the $\{001\}$ and $\{111\}$ directions for the whole sample. Crystallographic pole figures are plotted from electron channeling patterns. Stereographic plots are equal-area, lower hemisphere projections. Inverse pole figures are shown beneath each set of stereoplots. All stereoplots are in the same reference frame with the margin of the shear zone oriented vertically in an east-west direction. The number of grains (n) measured for each sample is indicated. The crystal symmetries of magnetite and ilmenite mean that larger numbers of points can be plotted for some crystal directions (multiples of the numbers of grains depending on the symmetry).

in the center of the shear zone. The constant backscatter intensity across this grain suggests that it is relatively undeformed. At one end of the crystal, there is a "pressure shadow" region where Fe-Ti oxide minerals have precipitated in a "tail" that tapers away from the grain along the shear zone (Pl. 2 (ps); Pl. 5, Fig. 1). The Fe-Ti-oxide segregations tend to include more pyroxene neoblasts and porphyroclasts than plagioclase (Pl. 2). Pyroxene neoblasts are identified by their finer grain size, polygonal grain morphologies, and lack of intracrystalline deformation. Porphyroclasts are larger, have more irregular morphologies, and commonly display irregular undulose extinct and kink bands. They are also partly rimmed by polygonal, recrystallized grains. Fe-Ti oxides outside the shear zone are mainly alteration products of clinopyroxene.

In the shear zone, the grain size of the Fe- $\mathrm{Ti}$ oxides varies from 300 to $400 \mu \mathrm{m}$ in zones oriented obliquely (about $40^{\circ}$ ) to the shearzone margins, to less than $30 \mu \mathrm{m}$ in stringers parallel to the shearzone margins. The grain boundaries of the $\mathrm{Fe}$ - $\mathrm{Ti}$ oxides vary from a gently curved profile to straight boundaries enclosing polygonal grains with $120^{\circ}$ triple junctions. Grain boundaries are marked by discrete, continuous joints, and by trails of small $(<5 \mu \mathrm{m})$ voids. We do not think that the voids were formed by plucking because their size and spacing are very constant and they are a ubiquitous feature at grain boundaries. If some other mineral occupied these voids, we would expect to see at least some relict grains preserved, but none is evident. Within the magnetite, there are ilmenite needles that do not appear to be deformed and have no preferred orientation (Pl. 5, Fig. 1). The ilmenite preserves narrow exsolution lamellae of magnetite.

Recrystallized olivine is present, but only in the wallrock of the shear zone. The plagioclase is strongly recrystallized within the shear zone, and neoblast sizes range mainly from 30 to $50 \mu \mathrm{m}$. Plagioclase in the shear zone has a lower atomic number contrast relative to plagioclase outside the shear zone in which there is a reduction in the An number of plagioclase (from $\mathrm{An}_{70}$ to about $\mathrm{An}_{40}$ ) (Pls. 2, 5). The 
patchy backscatter contrast intensity in the plagioclase matrix of the wallrock also indicates the heterogeneous plagioclase compositions (Pl. 5, Fig. 2). Outside the shear zone, the plagioclase and clinopyroxene grains that form a poikilitic texture are weakly elongated parallel to the shear zone, and the poikilitically included plagioclase is also weakly aligned. Within the pyroxene crystals, amphibole alteration has localized along the polygonal, recrystallized grain boundaries, giving them a "decorated" appearance. Actinolite veins trend subparallel to the shear zone and cut the recrystallized plagioclase and pyroxene grains. In two locations, actinolite veins also appear to cut thin oxide stringers. All phases are cut by chlorite veins, oriented subperpendicular to the shear-zone margins. These, in turn, are cut by chlorite veins at a high angle to the shear zone ( $\mathrm{Pl} .2)$.

\section{Sample 153-921E-5R-1, 0-6 cm}

This shear zone is one of several within segregations of Fe-Ti oxides in a dynamically recrystallized matrix of plagioclase and clinopyroxene. Weakly defined layering is defined by modal variations in plagioclase and clinopyroxene (Pl. 3). The bulk mineralogy of the shear zone is approximately $50 \%$ magnetite, $30 \%$ ilmenite, and $20 \%$ plagioclase. There are steep gradients in the grain size of ilmenite, magnetite, and plagioclase $(<20 \mu \mathrm{m}$ to $>300 \mu \mathrm{m})$ towards the margins of most plagioclase porphyroclasts. The porphyroclasts have a shape-preferred elongation parallel to the Fe-Ti oxide stringers. This sample is not oriented, and structures can therefore only be related to the shear-zone margins. A network of magnetite surrounds aggregates of ilmenite and plagioclase grains that have their long axes oriented subparallel to the shear-zone margin (Pl. 2; Pl. 5, Fig. 3). The magnetite grains do not have a preferred dimensional orientation. The grain boundaries of both magnetite and ilmenite are more irregular than those in Sample 153-922A-2R-5, 83-87 cm, although straight grain boundaries and polygonal grains exist. In contrast to Sample 153-922A-2R-5, 83-87 cm, there are no ilmenite needles in the magnetite grains. The orientation contrast image (PI. 5, Fig. 3) shows a fairly homogeneous backscatter intensity in the magnetite, indicating that little or no internal deformation of the grains has been preserved. It is still possible to observe orientation contrast in magnetite even though it has a high symmetry $(\mathrm{Fd} 3 \mathrm{~m})$. In some places the grain boundaries of the magnetite protrude into ilmenite grains with lobate and tapering morphologies (Pl. 5, Figs. 3, 4). Some of these "protrusions" are isolated by grain boundaries from the host grain, whereas others are in crystallographic continuity.

Aspect ratios of the ilmenite aggregates reach maximum values of about 1:5. In other parts of the sample, ilmenite also forms more continuous stringers. As for magnetite, well-developed triple junctions (Pl. 5, Fig. 3) are present together with more irregular tapering and lobate boundaries, but, in contrast, the ilmenite also has a well-developed subgrain fabric (PI. 2; Pl. 5, Fig. 3). The appearance of subgrains on the orientation contrast image is similar to that of undulose extinction under cross-polars on the optical microscope. Grains are generally subequant, and exhibit the same local grain boundary characteristics, irregularities, and protrusions as the magnetite grains. The ilmenite grain size is generally smaller than the magnetite grains, but the grain-size reduction gradient in ilmenite grain size towards the porphyroclast boundary is not as steep as that for the magnetite (see grain-size analysis below). Over $80 \%$ of the ilmenite grains contain subgrains. The Fe-Ti-oxide segregation is traversed by transgranular, open cracks oriented at a high angle to the shear-zone margin. Plagioclase is slightly altered by chlorite, and undeformed chlorite veins cut across both the oxide phases and plagioclase.

\section{Sample 153-921E-2R-2, 58-60 cm}

The mylonitic shear zone in Sample 153-921E-2R-2, 58-60 cm, preserves compositional banding defined by modal variations in pla- gioclase, clinopyroxene, and $\mathrm{Fe}-\mathrm{Ti}$ oxides. Some bands contain $>70 \%$ plagioclase, and others contain $25 \%-30 \%$ magnetite, $5 \%-$ $10 \%$ ilmenite, $15 \%-25 \%$ plagioclase, and about $30 \%-40 \%$ clinopyroxene ( $\mathrm{Pl} .4)$. Overall, the grain size in the mylonite is much smaller $(<5-100 \mu \mathrm{m})$ than it is in the other two shear zones used in this study. The Fe-Ti-oxide-rich bands contain fragments of undeformed porphyroclasts and dynamically recrystallized clinopyroxene (Pl. 5, Figs. 5, 6). The grain boundaries of the magnetite are highly irregular, displaying lobate and tapering grain morphologies, but a few equant grains, displaying $120^{\circ}$ triple junctions are also present. As in Sample 153-921E-5R-1, 0-6 cm, there are no ilmenite needles preserved within the magnetite grains. Some magnetite grains partially or completely enclose recrystallized grains of plagioclase or clinopyroxene (the recrystallized grains are identified by their size and morphology) (Pl. 5, Fig. 7). The curved magnetite grains, however, do not show any crystallographic distortion in the orientation contrast image or in electron channeling patterns. The plagioclase exhibits polygonal grain morphologies that have grain sizes of about $50 \mu \mathrm{m}$ and that are slightly reduced in the Fe-Ti-oxide-rich bands. Ilmenite, in contrast to the shear zone in Sample 153-921E-5R-1, 0-6 cm, does not display subgrains and is a comparatively minor component in the bulk mineralogy. Ilmenite generally occurs as isolated grains adjacent to magnetite grains with moderately curved to straight grain boundaries. The Fe-Ti oxides, plagioclase, and pyroxenes are cut by chlorite veins oriented at a high angle to the shear-zone margin (Pl. 5, Fig. 7).

\section{CRYSTALLOGRAPHIC FABRICS}

Electron channeling patterns for magnetite in each of the three regions (pressure shadow region, coarse-grained, and fine-grained) in Sample 153-922A-2R-5, 83-87 cm, have slightly different characteristics, but none shows a strong clustering of points that would indicate a strong crystallographic preferred orientation. Inverse pole figures and lower hemisphere plots for the poles to $\{001\}$ and $\{111\}$ in magnetite are shown in Figures 4-7. In the pressure shadow plots, a weak star-shaped pattern is evident for poles to $\{001\}$ and a similar pattern may also be present for the poles to $\{111\}$ (Fig. 4). The pole distribution in these patterns forms branches, separated by about $45^{\circ}$, radiating from the center. Although there are blank spots in the stereographic plots for poles to $\{001\}$ in the fine-grained and coarsegrained regions, we cannot identify symmetries in the point distributions.

In Sample 153-921E-5R-1, 0-6 cm, the pole figure $\{001\}$ in magnetite also displays a weak "star-like" pattern, but no patterns can be identified in other pole figures $(\{011\},\{111\},\{112\}$; Fig. 5). Surprisingly, even in the fine-grained mylonite, Sample 153-921E-2R-2, $58-60 \mathrm{~cm}$, the magnetite fabrics show no strong preferred orientation (Fig. 7). The pole figure for $\{001\}$ has less symmetry than those of the other two samples, although both $\{001\}$ and $\{111\}$ pole figures have significant gaps in the point distribution.

Although the number of data points is relatively small, the weak star pattern for poles to $\{001\}$ resembles the rolling textures generated in face-centered cubic metals, possibly indicating $\{111\}$ glide. The pole figures for $\{111\}$ are also not random, but the relatively small number of points prevents a statistically valid identification of any symmetry or specific slip system.

In contrast to the magnetite textures, the ilmenite grains in Sample 153-921E-5R-1, 0-6 cm, exhibits a strong preferred orientation of the pole to $\{0001\}$, which is oriented at a high angle to the inferred shear plane (east-west vertical line). The $\{1-100\}\{11-20\}$ poles form broad girdles parallel to the shear plane, but as yet a slip direction has not been identified (Fig. 6). These fabrics resemble those formed by basal slip in other trigonal minerals (e.g., quartz). No symmetries are evident in the ilmenite patterns for either of the other two 
samples (Sample 153-922A-2R-5, 83-87 cm, and 921E-2R-2, 58-60 $\mathrm{cm})$.

\section{GRAIN-SIZE DISTRIBUTIONS}

Recrystallized grain sizes were measured for ilmenite and magnetite in Samples 153-921E-5R-1, 0-6 cm, and 2R-2, 58-60 cm, using the linear intercepts to obtain chord-length distributions (Spektor, 1950; Underwood, 1970). Ilmenite subgrain sizes were also measured in Sample 153-921E-5R-1, 0-6 cm, in which the grain-size distributions were compared for a fine-grained region adjacent to a plagioclase porphyroclast on the margin of the shear zone and the overall coarser grain size in the central region of the shear zone (PI. 3).

Grain-size measurements display the commonly acquired lognormal distribution for material particle grain sizes, which may result, in part, from the overemphasis of small grain sizes. To obtain the volume percent distribution, the distribution frequencies were adjusted (smoothed) assuming a log-normal distribution. The smoothed frequency distributions for the raw data are shown in Figure 8. A larger number of measurements (ideally 1000) are needed to smooth the distribution profiles. In Sample 153-921E-5R-1, 0-6 cm, the magnetite grain size in the fine-grained region ranges from 6.25 to $237 \mu \mathrm{m}$ with a modal grain size of $10 \mu \mathrm{m} ; 70 \%$ of the grains fall between 10 and $40 \mu \mathrm{m}$. Ilmenite in this region does not exhibit such a marked grain-size reduction. The minimum and maximum ilmenite grain sizes are less than 2 to $338 \mu \mathrm{m}$ with a mode of $60 \mu \mathrm{m} ; 70 \%$ of the grains fall in the range from 40 to $80 \mu \mathrm{m}$. In the coarser-grained region in the main shear zone, the magnetite grain size ranges from 10 to $600 \mu \mathrm{m}$ with a mode of $40 \mu \mathrm{m} ; 70 \%$ of the data fall within the range from 20 to $100 \mu \mathrm{m}$. Ilmenite grains range from 10 to $444 \mu \mathrm{m}$ with a mode of $60 \mu \mathrm{m} ; 70 \%$ of the data fall between 20 and $100 \mu \mathrm{m}$. Ilmenite subgrains range from less than 2 to $253 \mu \mathrm{m}$ with a modal subgrain size of $50 \mu \mathrm{m} ; 70 \%$ of the data fall between 20 and $80 \mu \mathrm{m}$.

In Sample 153-921E-2R-2, 58-60 cm, magnetite data were divided for transects perpendicular and parallel to the shear zone. In the set that was parallel to the shear zone, the grain size ranges from less than 2 to $56 \mu \mathrm{m}$. The modal grain size is $10 \mu \mathrm{m}$, and $70 \%$ of the data fall below $15 \mu \mathrm{m}$. In the transects perpendicular to the shear zone, the grain size ranges from less than 2 to $48 \mu \mathrm{m}$ with a modal grain size of $8 \mu \mathrm{m} ; 70 \%$ of the data fall in the range below $12 \mu \mathrm{m}$. These slight differences in grain size suggest a weak shape-preferred orientation with an elongation parallel to the shear zone. The ilmenite grain size ranges from less than 2 to $76 \mu \mathrm{m}$ with a mode of $10 \mu \mathrm{m} ; 70 \%$ of the data fall between 10 and $20 \mu \mathrm{m}$.

\section{GEOTHERMOMETRY}

The temperature during recrystallization of magnetite and ilmenite can be calculated using the geothermometer and oxybarometer of Buddington and Lindsley (1964) as revised by Spencer and Lindsley (1981). Mole fractions were calculated (following the procedures of Stormer, 1983) for magnetite and ilmenite grains from all three samples. (For example analyses, see Table 1). Temperature and oxygen fugacity estimates were read directly from the calibration graph of Spencer and Lindsley (1981).

The compositions of magnetite and ilmenite for Samples 153921E-5R-1, 0-6 cm, and 922A-2R-1, 83-87 cm, are very homogeneous, having mole fractions of 0.2 and 0.95 for ulvöspinel and ilmenite respectively. Sample 153-921E-2R-2, 58-60 cm, has a range in ulvöspinel mole fractions from 0.23 to 0.28 and ilmenite mole fractions from 0.96 to 0.99 . The ilmenite-magnetite geothermometer gives temperatures of about $630^{\circ} \mathrm{C}$ for Samples 153-921E-5R-1, 0-6 $\mathrm{cm}$, and $922 \mathrm{~A}-2 \mathrm{R}-1,83-87 \mathrm{~cm}$. Compositions for Sample 153-921E$2 \mathrm{R}-2,58-60 \mathrm{~cm}$, indicate a maximum temperature of about $610^{\circ} \mathrm{C}$
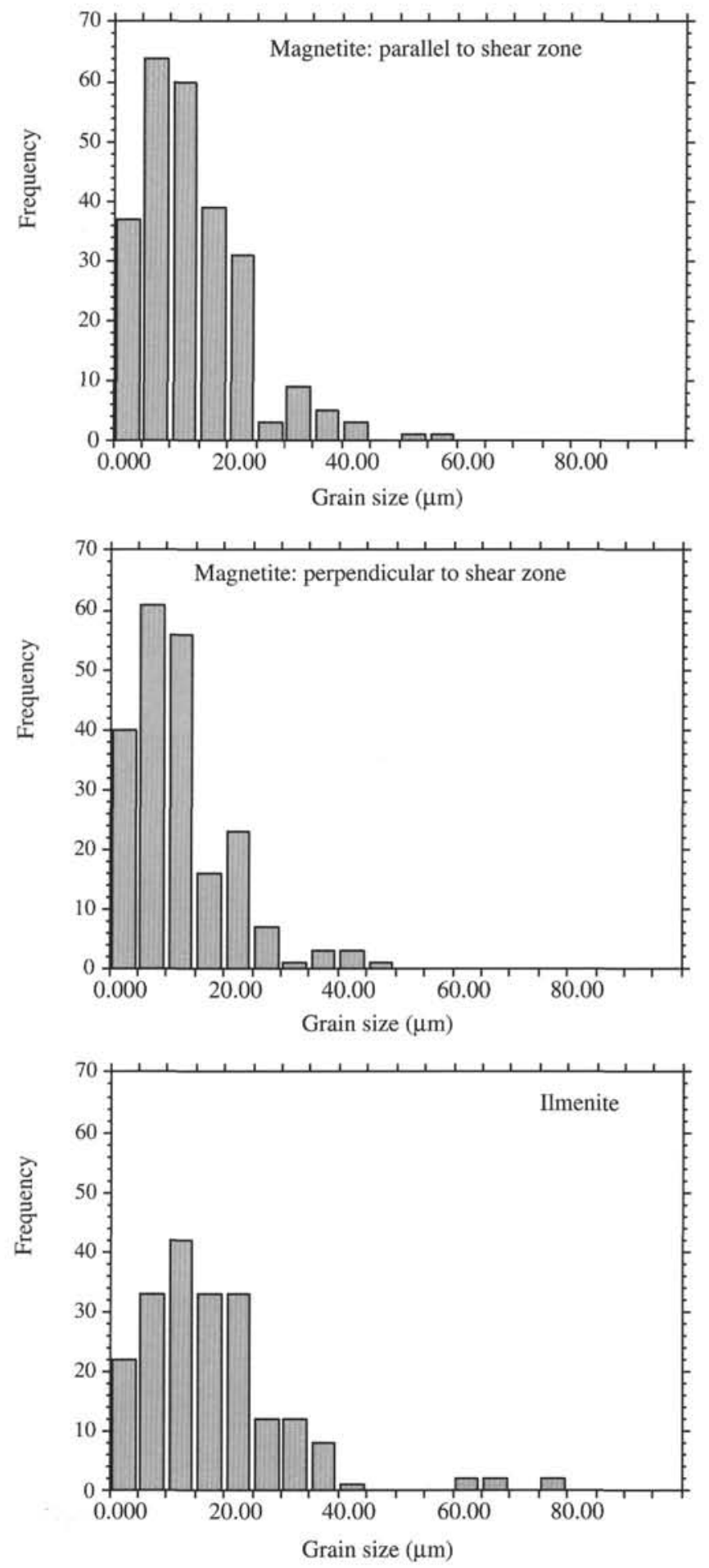

Figure 8. Grain-size distributions for Fe-Ti-oxide-bearing shear zones. A. Magnetite and ilmenite grain sizes for Sample 153-921E-2R-2, 58-60 cm. Magnetite grain sizes are divided to show slight differences between measurements parallel and perpendicular to the shear-zone margin. B. Subgrain and recrystallized grain size for ilmenite and magnetite in Sample 153-921E$5 \mathrm{R}-1,0-6 \mathrm{~cm}$. Recrystallized grain sizes for both ilmenite and magnetite are divided into "fine-grained" and "coarse-grained" regions of the sample. Subgrains are only present in ilmenite. 

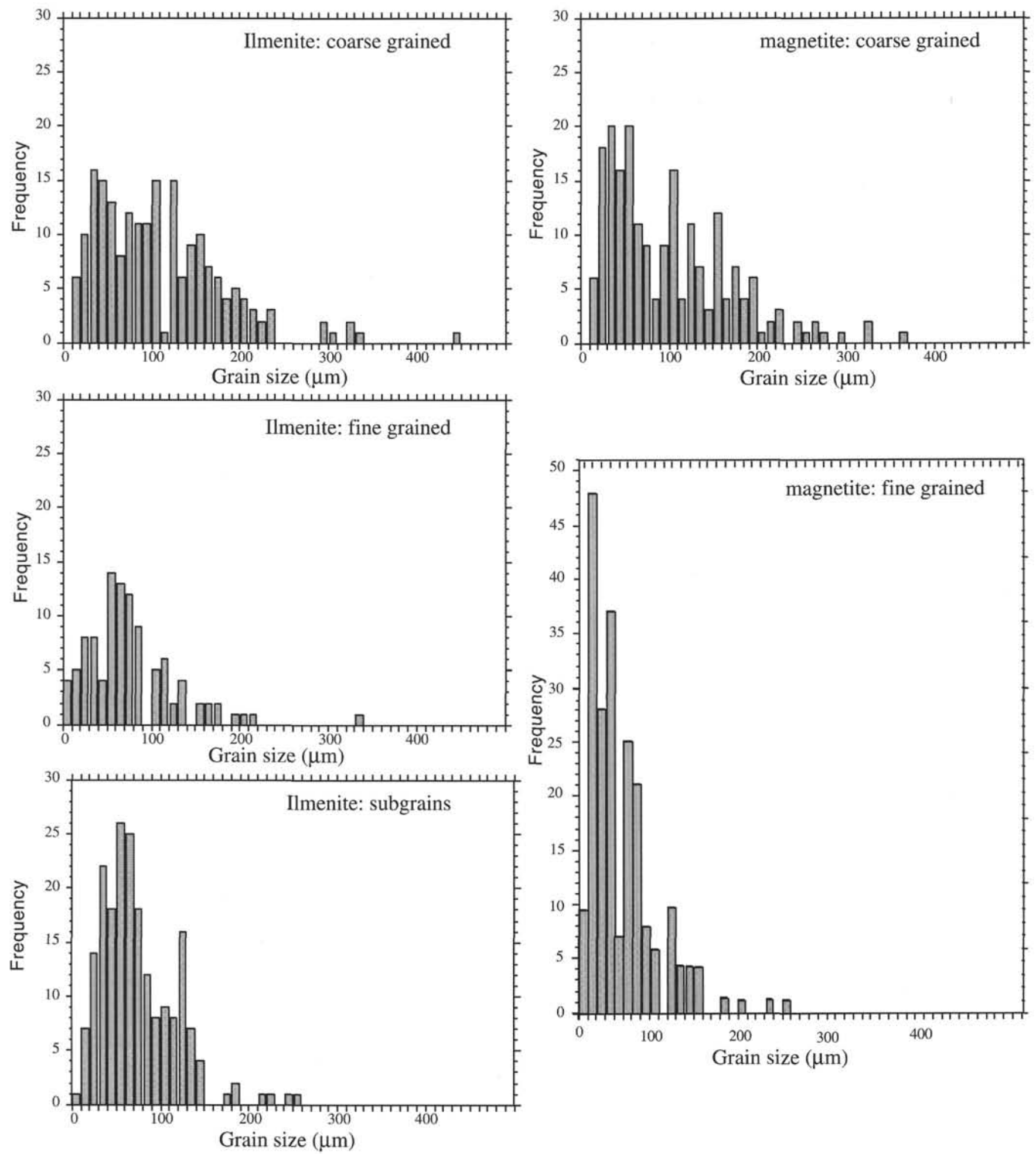

Figure 8 (continued), 
and a minimum temperature below $550^{\circ} \mathrm{C}$ where the geothermometer is uncalibrated.

\section{DEFORMATION MECHANISMS}

Using the grain-size distribution and the paleotemperature estimate, it is possible to place the magnetite and the ilmenite on deformation mechanism maps constructed by Atkinson (1977). These provide an estimate of the stress and strain-rate conditions for a fixed temperature and indicate the deformation mechanism that would have been operating under those conditions. Existing deformation maps have been constructed for temperatures of $662^{\circ} \mathrm{C}$ for polycrystalline magnetite and $675^{\circ} \mathrm{C}$ for polycrystalline hematite $\left(0.5 \mathrm{~T}_{\mathrm{m}}\right)$, which are reasonably close to the paleotemperature estimates (Fig. 9). No deformation mechanism maps have been constructed for ilmenite, but, given the similar crystal structure and compositional relation between ilmenite and hematite, the hematite map has been adopted here as a first approximation. The grain sizes for magnetite in the mylonitic shear zone (Sample 153-921E-2R-2, 58-60 cm, between 2 and $5 \mu \mathrm{m}$, (Fig. 8) would imply that diffusion creep was the dominant deformation mechanism for strain rates of $10^{-12} \mathrm{~s}^{-1}-10^{-14}$ $\mathrm{s}^{-1}$ (Fig. 9). The ilmenite grain size in the mylonite sample falls within the range for diffusion (Coble) creep. For the coarse-grained magnetite in Sample 153-921E-5R-1, 0-6 cm $(40 \mu \mathrm{m})$, dislocation creep would operate at strain rates higher than $10^{-13} \mathrm{~s}^{-1}$. In the fine-grained region of this sample, the grain size $(10 \mu \mathrm{m})$ indicates that dislocation creep would operate at strain rates above $10^{-10} \mathrm{~s}^{-1}$. The recrystallized grain size for ilmenite in this sample (about $60 \mu \mathrm{m}$ ) indicates dislocation creep at strain rates above $10^{-13} \mathrm{~s}^{-1}$, otherwise the deformation would be accommodated by Coble creep. Plotting the grain sizes for ilmenite on the hematite map places the samples entirely in the Coble creep field. This mechanism is inappropriate, given that the presence of subgrains in ilmenite and a strong crystallographic preferred orientation show that dislocation creep was operating. Errors in grainsize measurements, emphasizing the smaller end of the grain-size spectrum, the substitution of the hematite map for ilmenite, and the slightly higher temperature used for the map construction are all factors contributing to this error.

\section{PALEOPIEZOMETRY}

If steady-state dislocation creep can be demonstrated as the main deformation mechanism, then it is possible to estimate the peak differential stresses magnitudes from subgrain and recrystallized grain size (Twiss, 1977). Although these paleopiezometers have not been calibrated for ilmenite, experiments on other minerals and metals show that their grain-size distributions are well represented by these piezometers for the range of magnitudes of crustal stresses (from 10

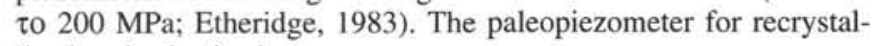
lized grain size is given as

$$
\log \sigma / \Gamma=0.91-\log d / b \text {. }
$$

The paleopiezometer for subgrain size is given as

$$
\log \sigma / \Gamma=0.38-0.68 \log d / b,
$$

where $\sigma$ is the differential stress in MPa; $\Gamma$ is the ratio of the shear modulus divided by the poisson ratio subtracted from $1(\mu /[1-v]), b$ is the burgers vector, and $\mathrm{d}$ is the grain diameter. From the microstructural observations, this assumption is reasonably valid for the ilmenite deformation in Sample 153-921E-5R-1, 0-6 cm, because of the presence of subgrains and neoblasts. The ilmenite in Sample 153-921E-2R-2, 58-60 cm, appears to be too fine grained to deform by dislocation creep under the assumed temperature conditions. Depending on the strain rate and differential stress conditions, some of the magnetite may have deformed by dislocation creep for part of the deformation history, but the lack of crystallographic preferred orientation argues against this. If the crystallographic fabric was obliterated by static recrystallization after dislocation creep, then the grain size may not be representative of the differential stress magnitudes. With these limitations in mind, the paleopiezometer of Twiss (1977) applied to the ilmenite in Sample 153-921E-5R-1, 0-6 cm, gives a differential stress magnitude of less than $75 \mathrm{MPa}$ for its recrystallized grain size of $60 \mu \mathrm{m}$, whereas the subgrain size $(50 \mu \mathrm{m})$ gives an estimate of about $50 \mathrm{MPa}$. These estimates should be considered only an approximation because of the lack of a suitable cali-

\begin{tabular}{|c|c|c|c|c|c|c|c|c|c|c|c|}
\hline Ilmenite & 1 & 2 & 3 & 4 & 5 & & & & & & \\
\hline $\mathrm{TiO}_{2}$ & 49.13 & 49.79 & 49.82 & 49.63 & 49.79 & & & & & & \\
\hline $\mathrm{Al}_{2} \mathrm{O}_{3}$ & 0 & 0 & 0 & 0 & 0 & & & & & & \\
\hline $\mathrm{Cr}_{2} \mathrm{O}_{3}$ & 0 & 0.03 & 0 & 0.05 & 0 & & & & & & \\
\hline $\mathrm{Fe}_{2} \mathrm{O}_{3}$ & 7.02 & 6.21 & 6.45 & 6.42 & 5.88 & & & & & & \\
\hline $\mathrm{FeO}$ & 41.97 & 42.52 & 42.48 & 42.31 & 42.66 & & & & & & \\
\hline $\mathrm{MnO}$ & 1.29 & 1.33 & 1.29 & 1.33 & 1.2 & & & & & & \\
\hline $\mathrm{MgO}$ & 0.2 & 0.21 & 0.22 & 0.24 & 0.2 & & & & & & \\
\hline $\mathrm{NiO}$ & 0 & 0 & 0.09 & 0 & 0 & & & & & & \\
\hline $\mathrm{CaO}$ & 0 & 0 & 0 & 0.02 & 0 & & & & & & \\
\hline Total & 99.61 & 100.1 & 100.37 & 99.99 & 99.72 & & & & & & \\
\hline $\mathrm{Fe}(\mathrm{t})$ as $\mathrm{FeO}$ & 48.29 & 48.1 & 48.28 & 48.09 & 47.95 & & & & & & \\
\hline & 1.865 & 1.88 & 1.877 & 1.876 & 1.887 & & & & & & \\
\hline $\mathrm{Al}$ & 0 & 0 & 0 & 0 & 0 & & & & & & \\
\hline $\mathrm{Cr}$ & 0 & 0.001 & 0 & 0.002 & 0 & & & & & & \\
\hline Magnetite & 1 & 2 & 3 & 4 & 5 & 6 & 7 & 8 & 9 & 10 & 11 \\
\hline $\mathrm{TiO}_{2}$ & 6.07 & 5.39 & 5.44 & 7.46 & 6.41 & 4.78 & 6.95 & 4.99 & 4.86 & 5.96 & 5.2 \\
\hline $\mathrm{Al}_{2} \mathrm{O}_{3}$ & 3.65 & 3.71 & 3.89 & 3.89 & 3.3 & 3.55 & 3.49 & 4.08 & 1.09 & 3.56 & 3.7 \\
\hline $\mathrm{Cr}_{2} \mathrm{O}_{3}$ & 0.02 & 0.05 & 0.1 & 0.06 & 0.11 & 0.12 & 0.05 & 0.02 & 0.07 & 0.07 & 0.03 \\
\hline $\mathrm{Fe}_{2} \mathrm{O}_{3}$ & 52.5 & 53.88 & 53.61 & 49.5 & 51.99 & 55.21 & 50.81 & 53.99 & 57.02 & 52.53 & 53.69 \\
\hline $\mathrm{FeO}$ & 35.88 & 35.52 & 35.63 & 37.2 & 36.24 & 34.95 & 36.42 & 35.03 & 34.68 & 35.76 & 34.84 \\
\hline $\mathrm{MnO}$ & 0.14 & 0.18 & 0.22 & 0.27 & 0.23 & 0.15 & 0.21 & 0.17 & 0.18 & 0.23 & 0.22 \\
\hline $\mathrm{MgO}$ & 0.4 & 0.29 & 0.31 & 0.29 & 0.27 & 0.37 & 0.33 & 0.4 & 0.04 & 0.33 & 0.36 \\
\hline $\mathrm{ZnO}$ & 0.17 & 0.19 & 0.14 & 0.24 & 0.16 & 0.15 & 0.24 & 0.13 & 0.04 & 0.13 & 0.19 \\
\hline $\mathrm{NiO}$ & 0.03 & 0.06 & 0.1 & 0.08 & 0.07 & 0 & 0.18 & 0 & 0.08 & 0.07 & 0.1 \\
\hline $\mathrm{CaO}$ & 0 & 0.03 & 0 & 0.02 & 0 & 0 & 0.03 & 0.05 & 0.07 & 0 & 0 \\
\hline Total & 98.86 & 99.29 & 99.45 & 99 & 98.78 & 99.29 & 98.7 & 98.85 & 98.14 & 98.65 & 98.33 \\
\hline
\end{tabular}

Table 1. Representative analyses of ilmenite and magnetite. 


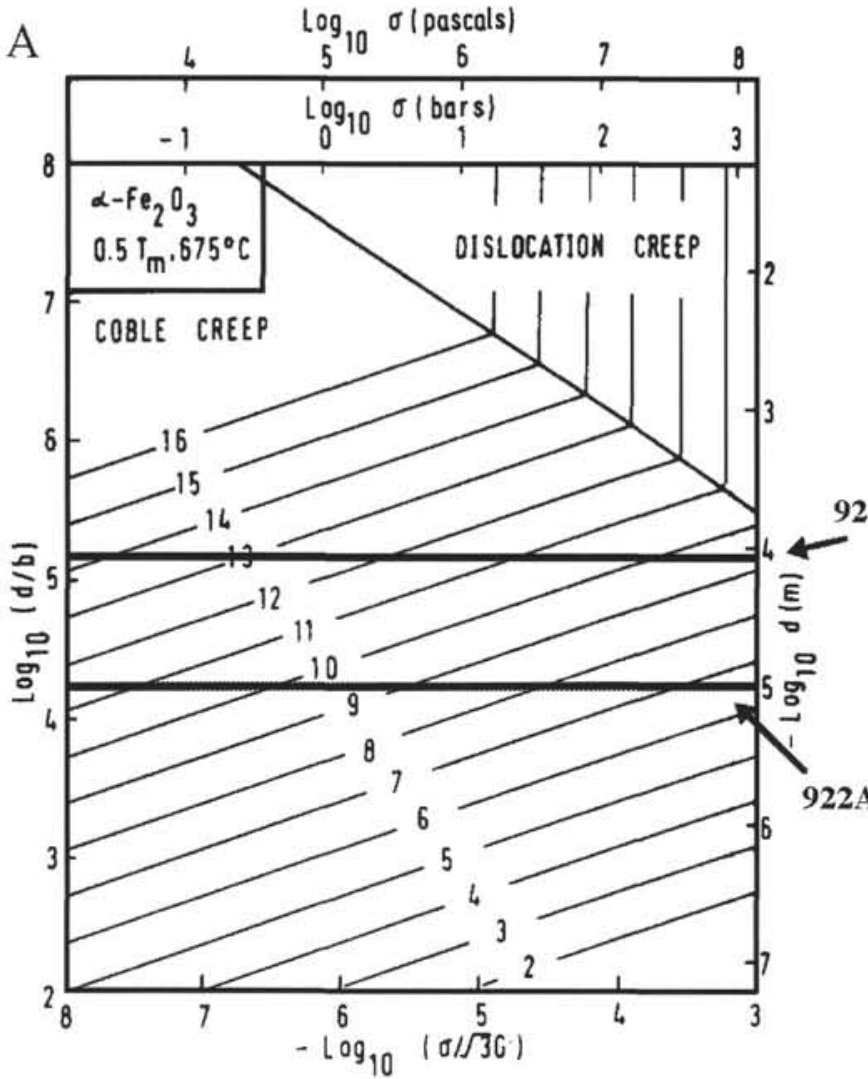

Hematite

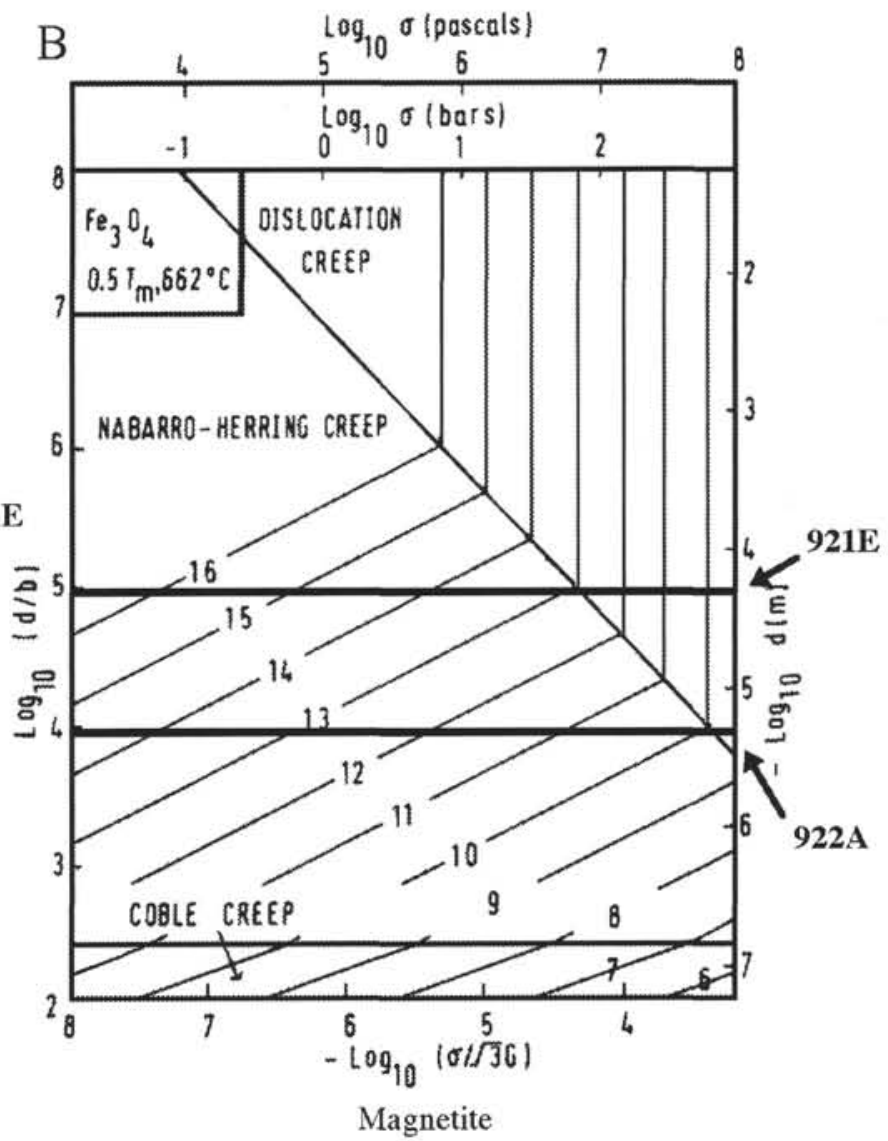

Figure 9. Deformation mechanism maps for (A) hematite and (B) magnetite (from Atkinson, 1977). Vertical axes are the negative log of recrystallized grain size (d) in meters (right-hand side), normalized by the burgers vector (b) on the left-hand side. The horizontal axis shows the differential stress magnitude (upper axis in pascals and bars, lower axis in the negative log of the normalized differential stress). Contours give the negative logs of strain rates $\left(\mathrm{s}^{-1}\right)$. The diagrams are constructed for temperatures of $675^{\circ} \mathrm{C}$ (hematite) and $662^{\circ} \mathrm{C}$ (magnetite). The modal ilmenite and magnetite grain sizes for two samples are shown by the horizontal lines (921E and 922A) on the hematite and magnetite maps respectively. 921E = Sample 153-921E-5R-1, 0-6 cm. 922A = Sample 153-922A-2R-2, $58-60 \mathrm{~cm}$.

bration and the assumptions used to calculate the values of constants used in the paleostress equations.

\section{DISCUSSION}

Melt migration plays an important role in controlling the timing and distribution of strain localization in the ocean crust both on-axis and as it moves off-axis (Agar, 1995). Changes in the bulk composition and the different deformation mechanism paths of phases within the shear zone are key aspects for constraining the rheological evolution of young oceanic shear zones. The shear zones investigated in this study demonstrate the interaction of melt migration and deformation during an overall down-temperature deformation history $\left(>900^{\circ}\right.$ to $550^{\circ} \mathrm{C}$ ) (see Agar et al., this volume). We argue that the resulting changes in composition and deformation mechanisms changed the strength of the shear zones and promoted ductile deformation at temperatures below those normally used to model the rheology of the ocean crust.

The concentrations of Fe-Ti-oxide phases within many shear zones indicate that the late-stage melt was linked to the deformation, either as a cause of slip or a passive response to slip. There are no constraints on how far the late-stage melt fraction has migrated, but textural relations indicate that the melt was mobilized. As the temper- ature decreased (below $900^{\circ}-700^{\circ} \mathrm{C}$ ), pyroxene would have started to deform brittley while plagioclase was still deforming by crystal plasticity. The post-kinematic growth of brown hornblende around the margins of recrystallized clinopyroxene suggests that dynamic recrystallization ceased at temperatures between $700^{\circ}$ to $900^{\circ} \mathrm{C}$ (Spear, 1981). We suggest that transgranular cracking in the pyroxene created a permeability, enabling melt in the wallrock to migrate into the shear zone. Thus, the contrasting rheology of plagioclase and pyroxene would tend to focus the $\mathrm{Fe}$ - $\mathrm{Ti}$ oxides along the pyroxene-rich segregations as observed.

Once the late-stage melt was introduced into the shear zone, the textural relations indicate several possible deformation paths. In Sample 153-922A-2R-5, 83-87 cm, the lack of intracrystalline deformation in both ilmenite and magnetite, the preservation of ilmenite needles within magnetite grains, and the comparatively straight grain boundaries suggest that either the $\mathrm{Fe}$ - $\mathrm{Ti}$ oxides crystallized with no further deformation or that deformation was overprinted by annealing. It is possible that both have occurred. We interpret the structures oriented at $40^{\circ}$ to the shear-zone margins as riedel shears (Pl. 2). Dilation during the riedel shear formation provided a pathway for invading melt that sealed the structure with little or no further deformation. Locally elevated melt pressures or the high ductility contrast between pyroxenes and the Fe-Ti oxides may have shielded the undeformed pyroxene grain in this shear zone. The stress distribution 
around the pyroxene grain could have generated the weak preferred orientation in the pressure shadow region (Pl. 2). The relatively coarse grain size and equant, straight-edged grain morphology supports post-kinematic grain growth in this sample.

In both Samples 153-921E-5R-1, 0-6 cm, and 2R-2, 58-60 cm, the more irregular grain morphologies and boundaries indicate that the $\mathrm{Fe}$ - $\mathrm{Ti}$ oxides were not in textural equilibrium and are therefore probably not primary crystallization morphologies. In Sample 153$921 \mathrm{E}-5 \mathrm{R}-1,0-6 \mathrm{~cm}$, the crystallographic preferred orientation and the presence of subgrains show that ilmenite has deformed by dislocation creep. The strong preferred $\{0001\}$ pole orientation is compatible with a basal $(\{0001\})$ slip mechanism. Given that the magnetite is interspersed with the ilmenite, the magnetite must also have been in a deforming zone, even though it shows only a very weak crystallographic preferred orientation. The nonrandom magnetite fabric may indicate that some dislocation creep accommodated deformation, but was not necessarily the dominant mechanism. The deformation mechanism map for magnetite indicates that deformation by diffusion creep is reasonable under the estimated lowermost deformation temperatures (about $550^{\circ} \mathrm{C}$ ). The magnetite may therefore have deformed by diffusion creep or possibly by fluid-assisted, grainboundary sliding. In the latter mechanism, interstitial melt would have accommodated the dependent grain boundary sliding of grains prior to final crystallization. Some synmagmatic deformation may be indicated by the curved morphology of magnetite grains that may represent a melt phase injected along grain boundary cracks. This interpretation is supported by the fact that the injection-shaped boundaries are in crystallographic continuity with anhedral magnetite "host" grains, although this could also be the result of diffusion creep. Post-kinematic annealing may have further weakened any deformation fabrics, but the grain boundary morphologies do not suggest extensive static recrystallization.

In Sample 153-922A-2R-2, 58-60 cm, neither the ilmenite nor the magnetite displays a strong crystallographic preferred orientation. The deformation mechanism maps indicate that for the finer grain size in this sample diffusion creep could have accommodated the deformation. The fragmentation and dispersal of pyroxene porphyroclasts within the mylonitic shear zone may indicate the melt-assisted fracturing. Alternatively, the fragmentation may have occurred during the simultaneous deformation of pyroxene and $\mathrm{Fe}$ - $\mathrm{Ti}$ oxides in which the higher strain rates in oxide matrix resulted in brittle failure in pyroxene inclusions. The very weak shape-preferred orientation of magnetite may have been caused by solution-precipitation creep at lower temperatures.

A lack of deformation features and bulk fabric has been noted previously in high-grade magnetite ores (Siemes, 1977) and may indicate that grain boundary sliding or diffusion creep is prevalent in other magnetite-bearing shear zones. In experiments on magnetite (room temperature to $400^{\circ} \mathrm{C}$ ) (Hennig-Michaeli and Siemes, 1982) the slip systems are partly dependent on the purity of the magnetite crystals. In impure (titaniferous) forms, all glide modes have been observed to operate over the $200^{\circ}-400^{\circ} \mathrm{C}$ range. In pure forms $\{111\}$ slip was not activated, but twinning on $\{111\}$ appears at a very low resolved shear stress. Compression experiments on magnetite ores at $25^{\circ} \mathrm{C}$ and $300^{\circ} \mathrm{C}$ at strain rates of $5 \times 10^{-4} \mathrm{~s}^{-1}$ (Muller and Siemes, 1972) revealed increasing ductility with increasing temperature and increasing confining pressure, with a marked temperature dependence. Reexamination of the deformed specimens by means of reflected light microscopy revealed abundant deformation twins in the $25^{\circ} \mathrm{C}$ specimens and fewer in the $300^{\circ} \mathrm{C}$ specimens (Hennig-Michaeli and Siemes, 1975). The lack of twinning in either phase in all samples in this study may indicate low resolved shear stresses or no deformation at temperatures below $400^{\circ} \mathrm{C}$. Sulfide ores have been studied more extensively than either ilmenite or magnetite and show similar low temperature crystal plasticity. Power law creep has been documented in sulfide ores over temperature ranges from $265^{\circ}$ to $375^{\circ} \mathrm{C}$ (Cox, 1987).

The migration of late-stage magma effectively concentrates these highly ductile oxide phases as a lining to the shear zones. Both our observations and experimental data support the low-temperature ductility of the Fe-Ti oxides. If these phases deform by dislocation creep, solution-precipitation creep, or diffusion creep down over temperatures of $200^{\circ}$ to $400^{\circ} \mathrm{C}$, then they may promote aseismic slip on spreading-segment faults at mid-ocean ridges. The steep geothermal gradient in young ocean crust means that crystal-plastic deformation would persist in Fe-Ti-oxide shear zones at shallow crustal levels (possibly less than $2 \mathrm{~km}$, depending on the original crustal structure). Whereas the mafic silicate phases would deform by brittle mechanisms below temperatures of about $600^{\circ} \mathrm{C}$ (or possibly higher, depending on the strain rate), the oxide phases would continue to deform by crystal-plastic mechanisms.

The shear-zone microstructures and petrofabrics illustrate the synchronous operation of different deformation mechanisms in individual shear zones and the changes in mechanisms that accompany changes in bulk composition and down-temperature deformation paths (Figs. 10, 11). These results not only demonstrate the time-dependent strength of polyphase shear zones, but also illustrate some of the processes that will modify acoustic and magnetic properties of deforming ocean crust. The interactions of magmatic fractionation, crystallization, and deformation in the ocean crust provides one possible explanation for the relatively low levels of seismicity on spreading-segment faults at mid-ocean ridges. Further investigations of natural shear zones formed at seafloor-spreading centers and appropriate experimental data are needed to revise existing models of ocean crust rheology that adopt monomineralic flow laws.

\section{ACKNOWLEDGMENTS}

We would like to thank Dr. D.J. Prior and Dr. J.C. Doukhan for constructive manuscript reviews. Dr. E. Condliffe and Dr. R. Jones provided valuable assistance with microprobe analyses. The efforts of the Leg 153 Shipboard Scientific Party and the editorial review board are also gratefully acknowledged.

\section{REFERENCES}

Agar, S.M., 1995. Rheological evolution of the oceanic crust: a microstructural view. J. Geophys. Res., 99:3175-3200.

Atkinson, B.K., 1977. The kinetics of ore deformation: its illustration and analysis by means of deformation mechanism maps. Geol. Foeren. Stockholm Foerh., 99:186-197.

Bloomer, S.H., Meyer, P.S., Dick, H.J.B., Ozawa, K., and Natland, J.H., 1991. Textural and mineralogic variations in gabbroic rocks from Hole 735B. In Von Herzen, R.P., Robinson, P.T., et al., Proc. ODP, Sci. Results, 118: College Station, TX (Ocean Drilling Program), 21-39.

Buddington, A.F., and Lindsley, D.H., 1964. Iron-titanium oxides minerals and synthetic equivalents. J. Petrol., 5:310-357.

Cannat, M., Karson, J.A., Miller, D.J., et al., 1995. Proc. ODP, Init. Repts., 153: College Station, TX (Ocean Drilling Program).

Cox, S.F., 1987. Flow mechanisms in sulphide minerals. Ore Geol. Rev., 2:133-171.

Detrick, R., Honnorez, J., Bryan, W.B., Juteau, T., et al., 1988. Proc. ODP, Init. Repts., 106/109: College Station, TX (Ocean Drilling Program).

Dick, H.J.B., Thompson, G., and Bryan, W.B., 1981. Low angle faulting and steady state emplacement of plutonic rocks at ridge-transform intersections. Eos, 62:406.

Etheridge, M.A., 1983. Differential stress magnitudes during regional deformation and metamorphism: upper bound imposed by tensile fracturing. Geology, 11:231-234.

Fynn, G.W., and Powell, W.J.A., 1979. Cutting and Polishing Optical and Electronic Materials. Bristol, United Kingdom (IOP Publish., Ltd.). 
Hennig-Michaeli, C., and Siemes, H., 1975. Zwillingsgleitung beim Magnetit (Twin gliding of magnetite). Neues. Jahrb. Mineral. Abh., 123:330334.

1982. Compression experiments on natural magnetite crystals at $200^{\circ} \mathrm{C}$ and $400^{\circ} \mathrm{C}$ at $400 \mathrm{MPa}$ confining pressure. In Godman, R.E., and Heuze, F.E. (Eds.), Issues in Rock Mechanics. Proc. 23rd Symp. Rock Mech., AIME, 380-388.

Housen, B.A., van der Pluijm, B.A., and Essene, E.J., 1995. Plastic behavior of magnetite and high strains obtained from magmatic fabrics in the Parry Sound shear zone, Ontario Grenville Province. J. Struct. Geol., 17:265-278.

Karson, J.A., and Dick, H.J.B., 1983. Tectonics of ridge-transform intersections at the Kane Fracture Zone. Mar. Geophys. Res., 6:51-98.

Karson, J.A., Thompson, G., Humphris, S.E., Edmond, J.M., Bryan, W.B., Brown, J.R., Winters, A.T., Pockalny, R.A., Casey, J.F., Campbell, A.C., Klinkhammer, G., Palmer, M.R., Kinzler, R.J., and Sulanowska, M.M., 1987. Along-axis variations in seafloor spreading in the MARK area. Nature, 328:681-685.

Lloyd, G.E., 1985. Review of instrumentation, techniques and applications of SEM in mineralogy. In White, J.C. (Ed.), Applications of Electron Microscopy in Earth Sciences. Short Course-Mineral. Assoc. Can., 11:155-188.

, 1987. Atomic number and crystallographic contrast images with the SEM: a review of backscattered techniques. Mineral. Mag.. 51:3-19.

Lloyd, G.E., Hall, M.G., Cockayne, B., and Jones, D.W., 1981. Selected area electron channeling patterns from geological materials: specimen preparation, indexing and representation of patterns and application. Can. Mineral., 19:505-518.

Lord, G.W., and Willis, T.F., 1951. Calculations of air bubble size distribution from results of a Rosiwal traverse of Aerate Concrete. ASTM Bull., 177:56.

Mével, C., Cannat, M., Gente, P., Marion, E., Auzende, J.-M., and Karson, J.A., 1991. Emplacement of deep crustal and mantle rocks on the west median valley wall of the MARK area (MAR $23^{\circ} \mathrm{N}$ ). Tectonophysics, 190:31-53.

Muller, P., and Siemes, H., 1972. Zur Festigkeit und Gefügeregelung von experimentel verformten Magnetitersen. Neues Jahr Mineral. Abh., 117: $39-60$.
Reynolds, I.M., 1984. Tectonically deformed ilmenite in titaniferous iron ores of the Mambula complex, Zululand, South Africa. Can. Mineral., 22:411-416.

Russ, J.C., 1986. Practical Stereology: New York (Plenum).

Schmidt, N.-H. and Olesen, N.O., 1989. Computer-aided determination of crystal-lattice orientation from electron-channeling patterns in the SEM. Can. Mineral., 27:15-22.

Schulz, N.J., Detrick, R.S., and Miller, S.P., 1988. Two- and three-dimensional inversions of magnetic anomalies in the MARK area (Mid-Atlantic Ridge, $23^{\circ} \mathrm{N}$ ). Mar. Geophys. Res., 10:41-57.

Siemes, H., 1977. Fabric analysis and fabric development in ores. Geol. Foeren. Stockholm Foerh., 99:172-185.

Siemes, H., and Hennig-Michaeli, C., 1985. Ore minerals. In Wenk, H.-R. (Ed.), Preferred Orientation in Deformed Metals and Rocks: New York (Academy Press), 335-358.

Spear, F.S., 1981. An experimental study of hornblende stability and compositional variability in amphibolite. Am. J. Sci., 281:697-734.

Spektor, A.G., 1950. Distribution analysis of spherical particles in non-transparent structures. Zavod. Lab., 16:173.

Spencer, K.J., and Lindsley, D.H., 1981. A solution model for coexisting iron titanium oxides. Am. Mineral., 66:1189-1201.

Stormer, J.C., Jr., 1983. The effects of recalculation on estimates of temperature and oxygen fugacity from analyses of multicomponent iron-titanium oxides. Am. Mineral., 68:586-594.

Twiss, R.J., 1977. Theory and applicability of a recrystallized grain size paleopiezometer. Pure Appl. Geophys., 115:227-244.

Underwood, E.E., 1970. Quantitative Stereology: Reading, MA (AddisonWesley Publ.).

White, J.C., and Gibbons, W., 1994. Mylonitic deformation of deep-crustal granulite, Minas fault zone, Nova Scotia. Eos, 75:637.

Date of initial receipt: 3 August 1995

Date of acceptance: 20 March 1996

Ms 153SR-009 


\section{Down temperature}

deformation history
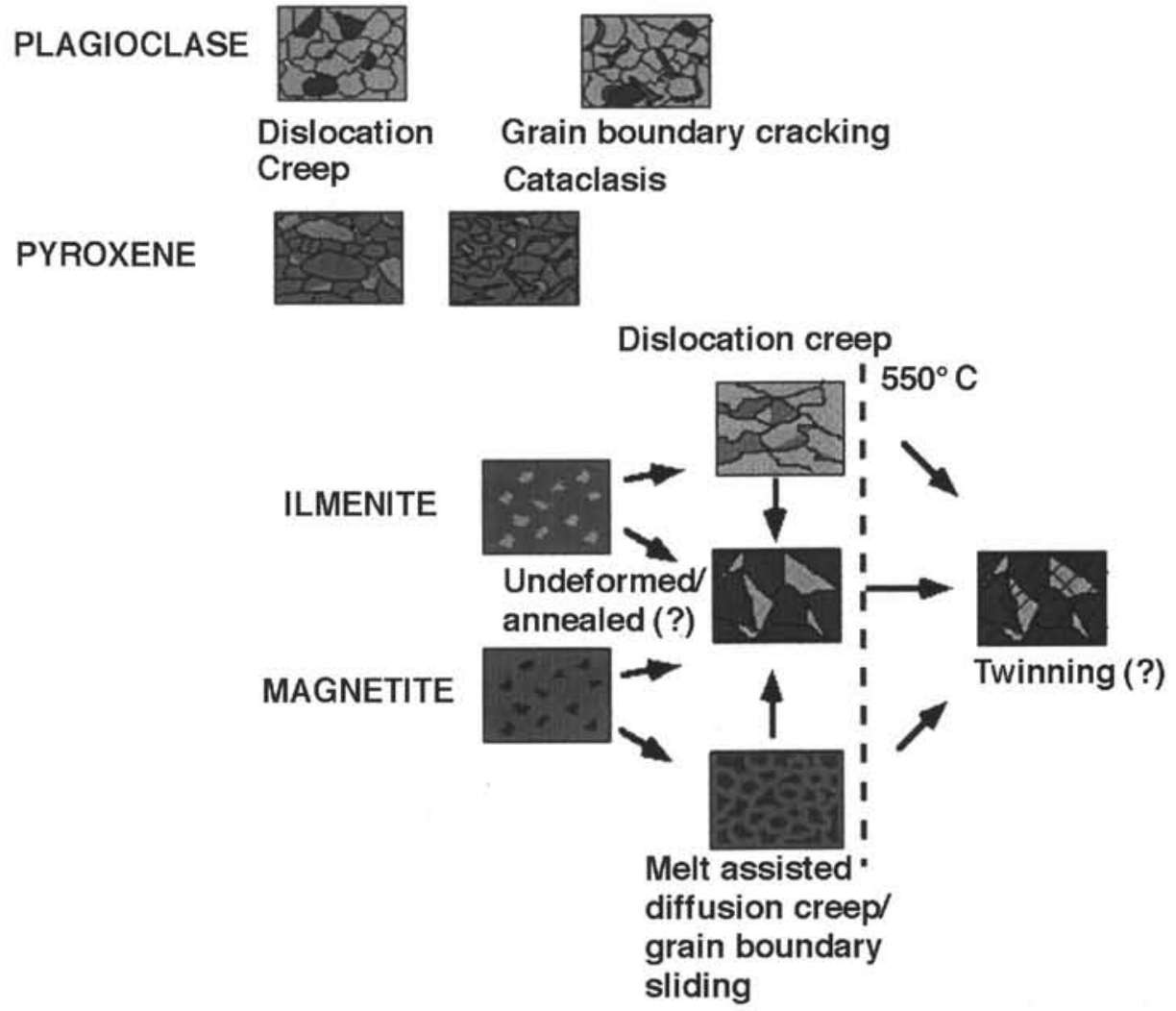

Figure 10. Summary of the interpreted deformation mechanism histories in Fe-Ti oxide shear zones from the MARK area. Early shear-zone deformation was accommodated by dislocation creep in plagioclase and pyroxene. As temperature decreased, fracturing initiated in pyroxene grains and may have been accompanied by some cracking along grain boundaries in plagioclase. Either during or after dynamic recrystallization, Fe-Ti oxides invaded the shear zone. The locally elevated melt pressures may have promoted fracturing in pyroxene and plagioclase. The association of Fe-Ti oxides with pyroxene-rich horizons suggests that cracking occurred mainly in pyroxene. The plagioclase may have continued to deform plastically while the pyroxene was fracturing. It is also possible that some Fe-Ti oxide concentrations existed in the protolith and were not derived from pockets of melt outside the shear zone. The higher ductility of the Fe-Ti oxides could have allowed them to flow into synkinematic fractures in the pyroxene under subsolidus conditions. Dislocation creep accommodated ilmenite deformation in one shear zone. Magnetite may have deformed by dislocation creep also, but subsequent annealing may have partly obliterated the crystallographic fabrics. Deformation by diffusion creep or melt-assisted grain boundary sliding may explain the lack of strong crystallographic fabrics in either the ilmenite or magnetite in two of the shear zones in this study. An alternative explanation is that melt injected during transient shear-zone dilatancy crystallized with no further deformation. In the case of Sample 153-921E-2R-5, 85-90 cm, the grain-shape morphology and undeformed ilmenite exsolution needles support this origin. In the mylonitic shear zone, Sample 153-922A-2R-2, 58-60 cm, the grain shapes are not characteristic of the polygonal morphologies commonly found in annealing textures and do not appear to be stable. Twinning is not present in ilmenite or magnetite in the samples studied here, although experimental data suggest that dislocation glide would operate at temperatures between $250^{\circ}$ and $400^{\circ} \mathrm{C}$ in magnetite.

Figure 11. Cartoon illustrating possible mesoscopic changes in a gabbroic shear zone at a slow-spreading center during off-axis motion or cooling on-axis. A. Distributed synmagmatic shear zones develop in crystal mush during late-stage magmatic fractionation. B. Strain localization in high-temperature shear zones (about $1000^{\circ} \mathrm{C}$ ) promotes segregation of plagioclase and pyroxene-rich bands. Some compositional segregations may be primary. Pockets of late-stage residual melts persist in surrounding gabbro. C. Cooling and/or possible local increases in melt pressure cause cracking in pyroxene crystals with continuing crystal plasticity in plagioclase. Residual melt migrates into and along the shear zone via permeable pathways in pyroxene-rich horizons. D. During continued shearing with decreasing temperature the pyroxene and plagioclase deform by brittle failure, but most of the strain localizes along the relatively weak $\mathrm{Fe}$ - $\mathrm{Ti}$ oxides that become concentrated as a lining within the shear zone.
Motion off-axis or cooling on-axis
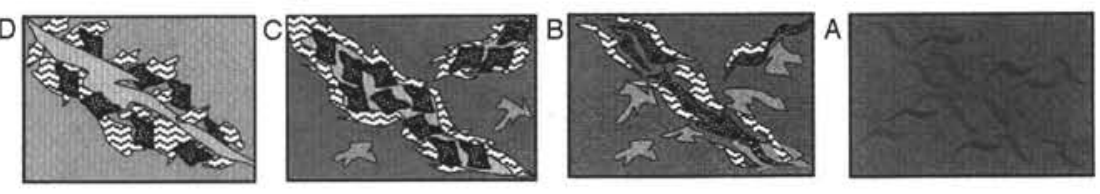

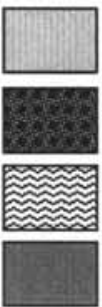

Residual melt enriched in $\mathrm{Fe}-\mathrm{Ti}$ oxides

Deformed pyroxene

in shear zone

Deformed plagioclase

in shear zone

Undeformed wall rock gabbro 

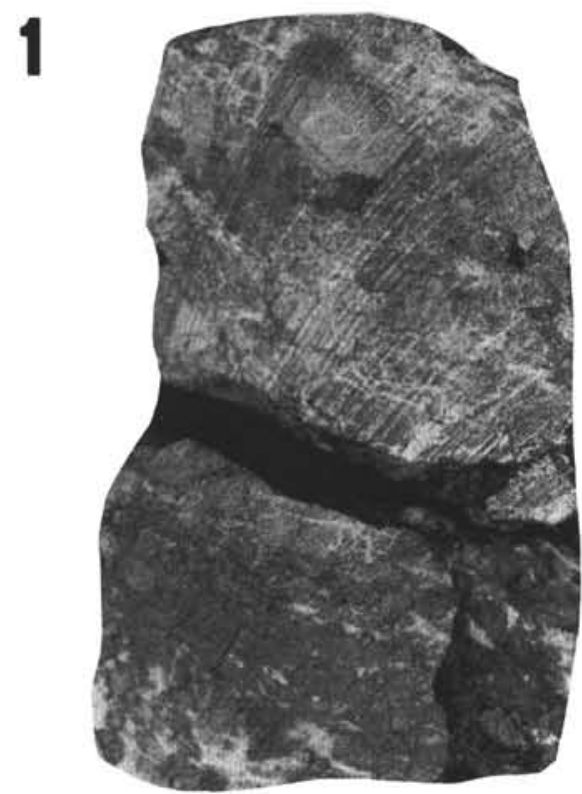

3

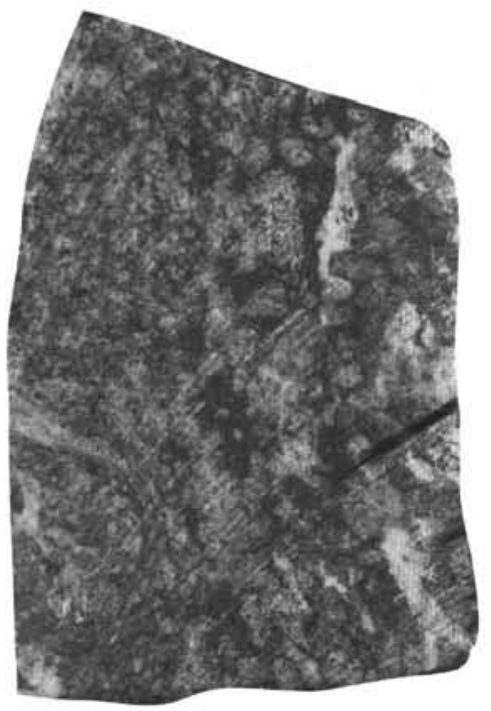

2

$-0 \mathrm{~cm}$

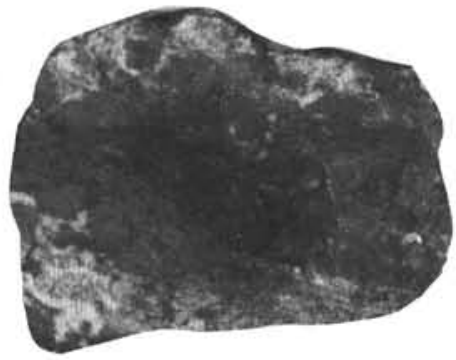

$0 \mathrm{~cm}$

$2 \mathrm{~cm}$

\section{$5 \mathrm{~cm}$}
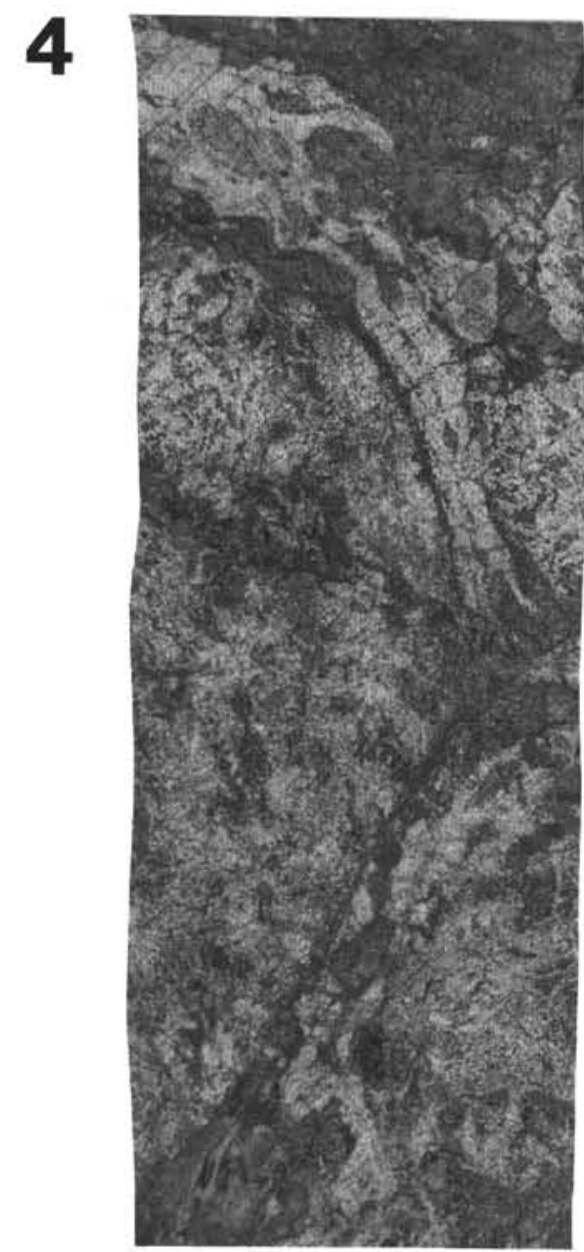

Plate 1. Core photographs of Fe-Ti-oxide-bearing shear-zone locations; 5-cm scale bar applies to Figures 1, 3, and 4; 2-cm scale bar applies to Figure 2 only. 1. Sample 153-921E-2R-2, 50-60 cm. An Fe-Ti-oxide-bearing mylonitic shear zone. 2. Sample 153-921E-5R-1, 0-6 cm. An Fe-Ti-oxide-bearing shear zone localized within a dynamically recrystallized gabbro. The gabbro has been invaded by a leucocratic melt (top and bottom of piece), which is also recrystallized. 3. Sample 153-921E-3R-1, 37-47 cm. An example of Fe-Ti oxide "stringers" (dark, center of core piece, oriented vertically) that permeate the dynamically recrystallized gabbro. This sample was not used for petrofabric analysis. 4. Sample 153-922A-2R-5, 85-90 cm. Fe-Ti-oxide-bearing shear zones traversing weakly recrystallized gabbro core. The two main shear zones link on the right-hand side of the core piece. 


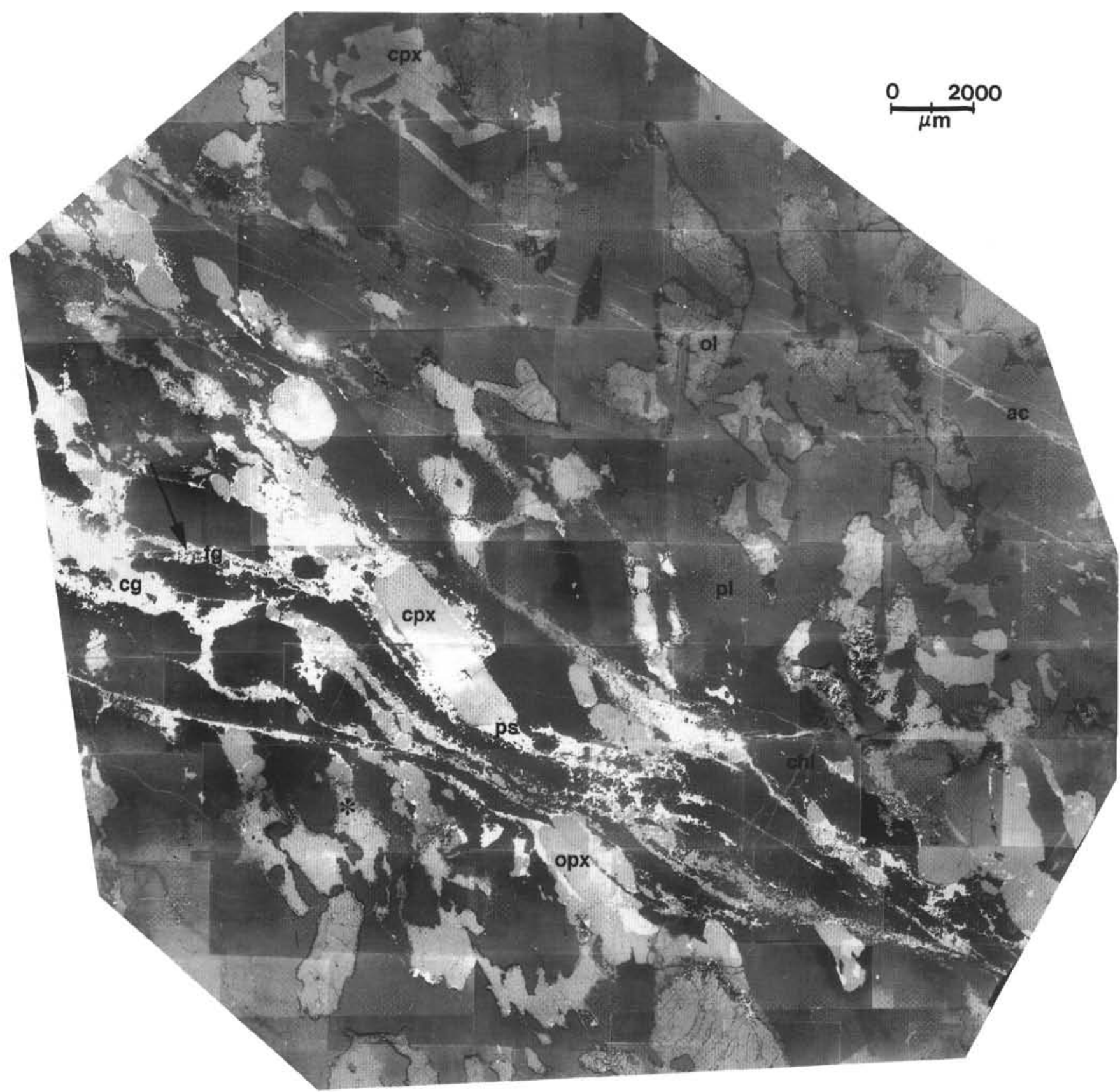

Plate 2. Backscattered electron image (BSE) in orientation contrast of shear zone in Sample 153-922A-2R-5, 83-87 cm. The shear zone trends from upper left to lower right. Mineral phases: $\mathrm{ac}=$ actinolite, $\mathrm{chl}=$ chlorite, $\mathrm{cpx}=$ clinopyroxene, opx $=$ orthopyroxene, $\mathrm{pl}=$ plagioclase, ol $=$ olivine. Areas used for fabric analysis: $\mathrm{cg}=$ coarse-grained, $\mathrm{fg}=$ fine-grained, $\mathrm{ps}=$ pressure shadow. The asterisk shows the location of Plate 5, Figure 2. See text for description. 


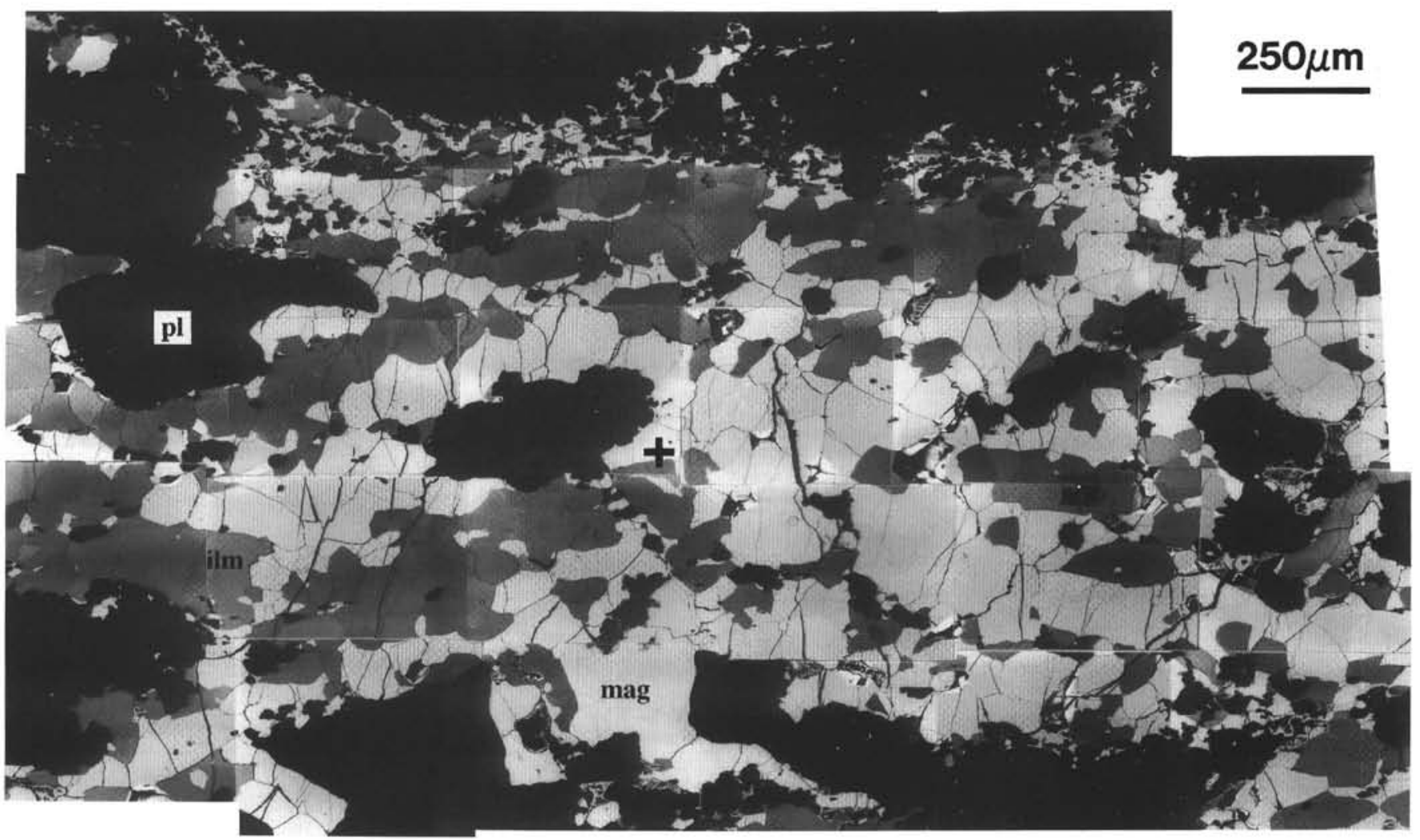

Plate 3. BSE images (orientation contrast) of shear zone in Sample 153-921E-5R-1, 0-6 cm. The shear-zone margin is horizontal. One margin of the shear zone can be seen in the upper part of the image where the grain size decreases. Mineral phases: ilm $=$ ilmenite, $\operatorname{mag}=$ magnetite and $\mathrm{pl}=$ plagioclase. Cross shows the location of Plate 5, Figures 3 and 4.

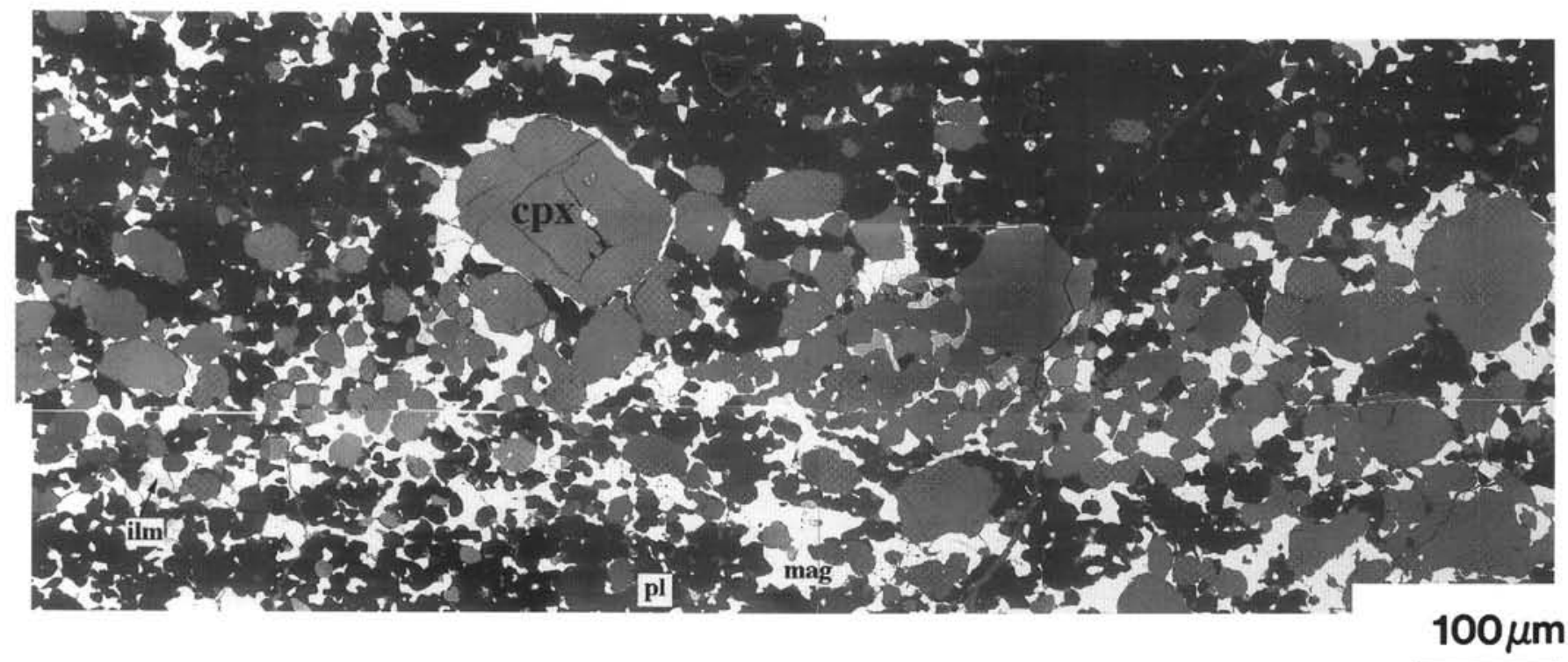

Plate 4. BSE images (orientation contrast) of mylonitic shear zone in Sample 153-921E-2R-2, 58-60 cm. The shear-zone margin is horizontal. Compositional banding within the shear zone consists of plagioclase-rich (upper part of image) and clinopyroxene- and Fe-Ti-rich bands (central and lower part of image). Mineral phases: $\mathrm{cpx}=$ clinopyroxene, ilm $=$ ilmenite, $\mathrm{mag}=$ magnetite, $\mathrm{mag}=$ magnetite. 
Plate 5. BSE orientation contrast images showing microstructural details of shear-zone montages. 1. Sample 153-922A-2R-5, 83-87 cm. Detail of pressure shadow region (ps) showing undeformed magnetite (mag) and ilmenite concentrated at the end of a clinopyroxene grain (cpx). Ilmenite needles within magnetite crystals (ilm, arrow) and ilmenite grains (ilm) are labeled. The dark phase (pl) is plagioclase. See Plate 2 for location. 2. Sample 153-922A-2R-5, 83-87 cm. Variation in backscatter intensity in plagioclase surrounding partially recrystallized orthopyroxene (see Pl. 2, asterisk). The polygonal grains at the upper margin of the image are clinopyroxene neoblasts. Chlorite veins cut the sample and fill grain boundary cracks around recrystallized grains. The darker region has a lower $\mathrm{An}$ number $\left(\mathrm{An}_{40}\right)$ than the lighter region surrounding the pyroxene porphyroclasts $\left(\mathrm{An}_{65}-\mathrm{An}_{70}\right)$. 3. Sample $153-921 \mathrm{E}-5 \mathrm{R}-1,0-6 \mathrm{~cm}$ (Pl. 3, see cross). Some of the recrystallized ilmenite grains (darker phase, ilm) have polygonal morphologies and $120^{\circ}$ triple junctions (t), whereas others have more lobate margins. Subgrain structures, shown by variations in gray scale that relate to mismatches in lattice orientation, are evident within ilmenite grains. Magnetite grains (lighter phase, mag) show no subgrain structure. In the upper right corner, an elongate magnetite grain (arrow) appears to invade a crack in an ilmenite grain (see PI. 3). Electron channeling reveals that there is no internal deformation of this grain. 4. Sample 153-921E-5R-1, 0-6 cm. Clinopyroxene (cpx) porphyroclast surrounded by $\mathrm{Fe}-\mathrm{Ti}$ oxides $(\mathrm{i} / \mathrm{m})$. The light stripes in the porphyroclast are exsolution lamellae. The margins of the porphyroclast are invaded by magnetite and ilmenite along tapering cracks (arrow) that are interpreted to have formed under locally elevated melt pressures during deformation. 5-7. Sample 153$922 \mathrm{~A}-2 \mathrm{R}-2,58-60 \mathrm{~cm}$ (see Pl. 4). Figure 5 shows an Fe-Ti oxide-rich band (bright phases) within a mylonitic shear zone suspending fractured clasts of recrystallized pyroxene (cpx). The large clast is a pyroxene porphyroclast. The dark matrix is mylonitized plagioclase. Figure 6 shows an enlargement of the clinopyroxene neoblasts suspended in the Fe-Ti oxide matrix. Figure 7 shows magnetite grains $(\mathrm{m})$ nearly enveloping recrystallized clinopyroxene grains. Electron channeling shows no intracrystalline deformation in the magnetite. The sample is cut by a chlorite vein (chl). The margins of clinopyroxene neoblasts are altered by brown amphibole. 


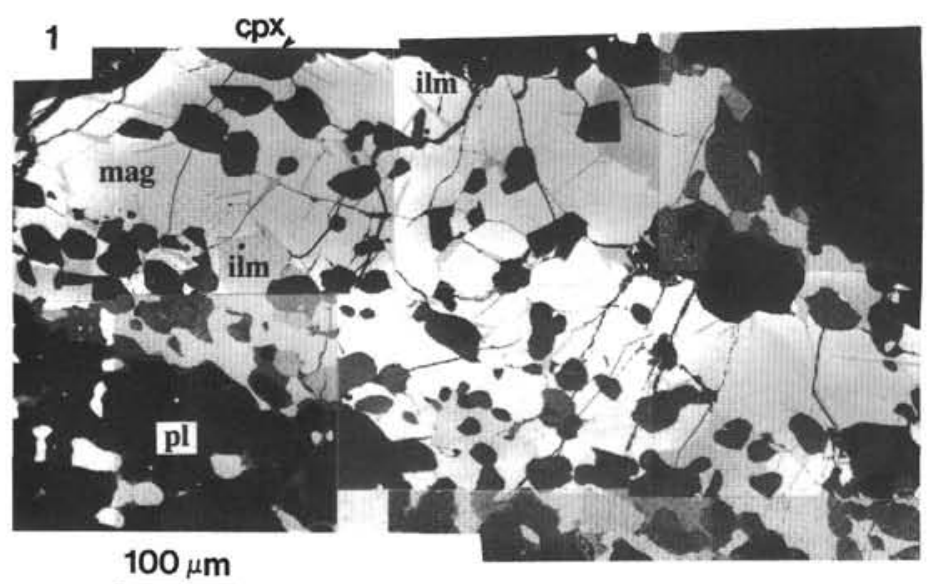

2

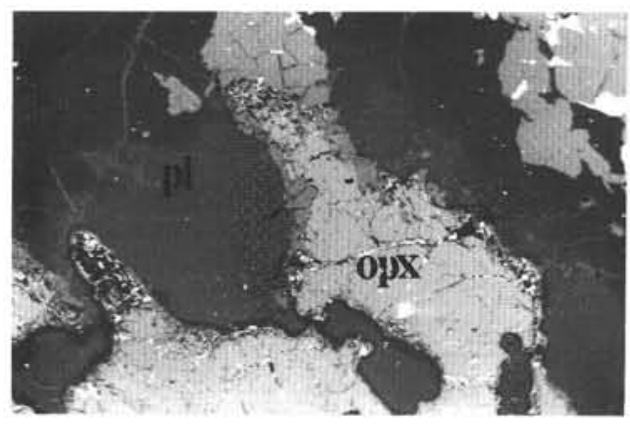

$300 \mu \mathrm{m}$

4

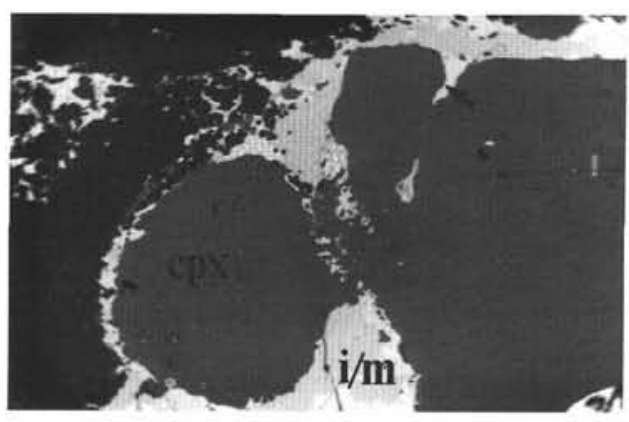

$300 \mu \mathrm{m}$

6

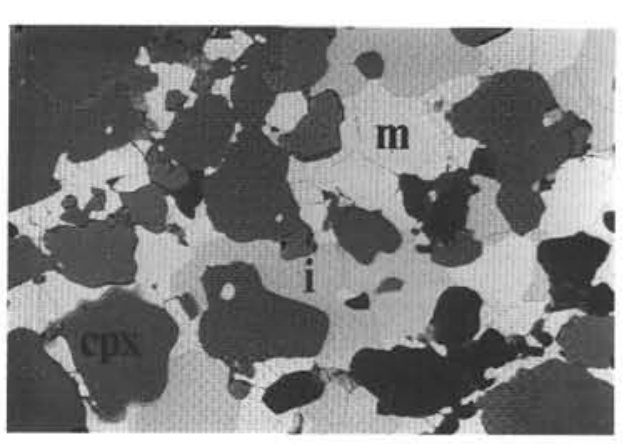

$100 \mu \mathrm{m}$

7

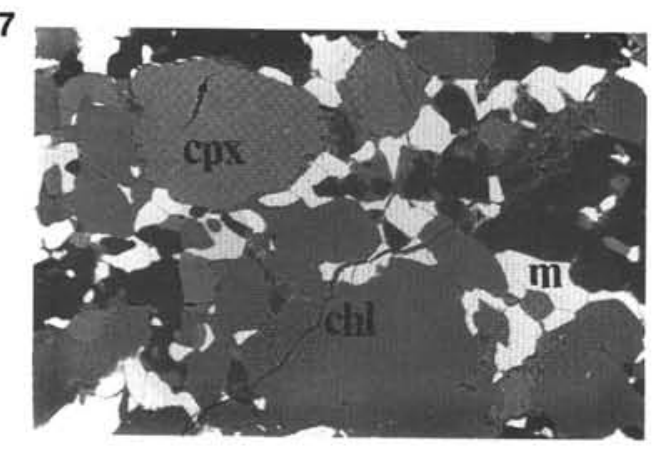

$30 \mu \mathrm{m}$ 